\title{
Characterization of the 12S rRNA Gene Sequences of the Harvester Termite Anacanthotermes ochraceus (Blattodea: Hodotermitidae) and Its Role as A Bioindicator of Heavy Metal Accumulation Risks in Saudi Arabia
}

\author{
Reem Alajmi ${ }^{1, *}$, Rewaida Abdel-Gaber ${ }^{1,2, *(1)}$ and Noura AlOtaibi ${ }^{3}$ \\ 1 Zoology Department, College of Science, King Saud University, Riyadh 11451, Saudi Arabia \\ 2 Zoology Department, Faculty of Science, Cairo University, Cairo 12613, Egypt \\ 3 Department of Biology, Faculty of Science, Taif University, Taif 21974, Saudi Arabia; \\ nj99alotaibi@hotmail.com \\ * Correspondence: ralajmi@ksu.edu.sa (R.A.); rewaida@sci.cu.edu.eg (R.A.-G.)
}

Received: 28 December 2018; Accepted: 3 February 2019; Published: 8 February 2019

\begin{abstract}
Termites are social insects of economic importance that have a worldwide distribution. Identifying termite species has traditionally relied on morphometric characters. Recently, several mitochondrial genes have been used as genetic markers to determine the correlation between different species. Heavy metal accumulation causes serious health problems in humans and animals. Being involved in the food chain, insects are used as bioindicators of heavy metals. In the present study, 100 termite individuals of Anacanthotermes ochraceus were collected from two Saudi Arabian localities with different geoclimatic conditions (Riyadh and Taif). These individuals were subjected to morphological identification followed by molecular analysis using mitochondrial $12 \mathrm{~S}$ rRNA gene sequence, thus confirming the morphological identification of $A$. ochraceus. Furthermore, a phylogenetic analysis was conducted to determine the genetic relationship between the acquired species and other termite species with sequences previously submitted in the GenBank database. Several heavy metals including $\mathrm{Ca}, \mathrm{Al}, \mathrm{Mg}, \mathrm{Zn}, \mathrm{Fe}, \mathrm{Cu}, \mathrm{Mn}, \mathrm{Ba}, \mathrm{Cr}, \mathrm{Co}, \mathrm{Be}, \mathrm{Ni}, \mathrm{V}, \mathrm{Pb}, \mathrm{Cd}$, and Mo were measured in both collected termites and soil samples from both study sites. All examined samples (termite and soil) showed high concentrations of metals with different concentrations and ratios. Generally, most measured metals had a significantly high concentration in soil and termites at Taif, except for Ca, $\mathrm{Cd}, \mathrm{Co}, \mathrm{Cr}, \mathrm{Cu}, \mathrm{Mg}$, and Ni showing significantly high concentrations at Riyadh. Furthermore, termites accumulated higher amounts of heavy metals than the soil at both locations. The mean concentrations of the measured metals in soil samples were found to be in the descending order $\mathrm{Ca}$ $>\mathrm{Al}>\mathrm{Mg}>\mathrm{Zn}>\mathrm{Fe}>\mathrm{Cu}>\mathrm{Mn}>\mathrm{Ba}>\mathrm{Cr}>\mathrm{Co}>\mathrm{Be}>\mathrm{Ni}>\mathrm{V}>\mathrm{Pb}>\mathrm{Cd}>\mathrm{Mo}$, while it was $\mathrm{Ca}>\mathrm{Mg}>\mathrm{Al}>\mathrm{Fe}>\mathrm{Zn}>\mathrm{Cu}>\mathrm{Mn}>\mathrm{Be}>\mathrm{Ba}>\mathrm{Pb}>\mathrm{Cr}>\mathrm{V}>\mathrm{Ni}>\mathrm{Cd}>\mathrm{Mo}>\mathrm{Co}$ in termite specimens. The mean concentrations of the studied metals were determined in the soil and termite specimens at both locations. In addition, the contamination factor, pollution load index (PLI) and degree of contamination were calculated for all studied metals in different samples, indicating that both studied sites were polluted. However, Taif showed a significantly higher degree of pollution. Thus, the accurate identification of economically important insects, such as termites, is of crucial importance to plan for appropriate control strategies. In addition, termites are a good bioindicator to study land pollution.
\end{abstract}

Keywords: Blattodea; molecular analysis; trace metals; accumulation; biological indicators 


\section{Introduction}

Termites are an interesting group of social insects that are widely distributed in low-land tropical ecosystems, where they can make up to $95 \%$ of the soil insect biomass [1]. The order Blattodea has been classified into 280 genera and over 2600 species within 12 families and 14 subfamilies [2]. The isopteran species are phylogenetically separated into lower termites (Mastotermitidae, Kalotermitidae, Hodotermitidae, Termopsidae, Rhinotermitidae, and Serritermitidae) and higher termites (Termitidae) [3,4]. Anacanthotermes is an Old-World genus of harvester termites in the Hodotermitidae. They are distributed in the deserts and semi-deserts of North Africa, the Middle East, and southwest Asia, including Baluchistan and southern India [5].

Lack of taxonomic understanding has been a major impediment to the study and management of termites [6]. The identification of termite species is challenging because of the ambiguity in their morphological characters and crypto-biotic social structure $[7,8]$. Molecular tools have become ways to complement the value of morphological taxonomy in addition to understand the evolutionary relationships among species. Molecular taxonomy based on mitochondrial DNA has proved to be an efficient alternative to the identification of species and determines their phylogenetic relationships $[9,10]$. DNA sequences of the mitochondrial genes of cytochrome oxidase subunit II (COX II) and the large (16S) and small (12S) subunits of ribosomal RNA (r RNA) have been used extensively for molecular diagnostics and to conduct comparative genetic analyses to study taxonomy, gene flow, colony characterization, and genetic variations $[4,11]$. Genetic diversity in subterranean termites was also studied using the random amplified polymorphic DNA (RAPD) markers [12].

Natural ecosystems all over the world have been adversely affected by human interventions [13]. Modern farming, industrialization, and increased vehicular use have led to high concentrations of heavy metals such as $\mathrm{Pb}, \mathrm{Ni}, \mathrm{Cr}, \mathrm{Cd}, \mathrm{Al}, \mathrm{Hg}$, and $\mathrm{Zn}$ in the environment [14]. These toxic heavy metals are regularly moved into air, water, and soil, thereby becoming a part of the natural biogeochemical cycle [15]. Insects have a strong relationship with ecology and have been frequently used as bioindicators [16]. The acute and chronic effects of heavy metals on various insects are reported frequently in the form of growth inhibition [17], developmental abnormalities [18], reduced reproduction [19], decreased hatchability [20], and alterations of respiratory and metabolic processes [21]. Insects are the agents of soil denudation owing to their feeding on soil as well as the construction of their nests in soil [22], and in the process accumulate large amounts of heavy metals in their bodies, resulting in physiological toxicity [23]. Furthermore, heavy metals could be moved to organism's higher position in the food chains resulting in bioaccumulation and eventual toxicity [24].

Therefore, the present study aimed to determine the morphological and molecular characterizations of the harvester termite Anacanthotermes ochraceus to determine its taxonomic position within the family Hodotermitidae and to assess whether this hodotermitid species could be used as a candidate bioindicator of soil heavy metals.

\section{Materials and Methods}

\subsection{Study Area}

Two distinct natural habitats in Saudi Arabia were selected for the current investigation: Site I at An-Nazim District, Eastern region of Riyadh City $\left(24^{\circ} 41^{\prime} 15.83^{\prime \prime} \mathrm{N}, 46^{\circ} 43^{\prime} 18.66^{\prime \prime}\right.$ E) and Site II at Arfaa District, Northern region of Taif City $\left(21^{\circ} 16^{\prime} 36.2892^{\prime \prime} \mathrm{N}, 40^{\circ} 22^{\prime} 28.1172^{\prime \prime} \mathrm{E}\right)$. Both sites are considered as polluted areas. Site I was characterized by the presence of sandy hills, some desert plants with high temperature, illegal dumping of raw sewage into public use areas, road traffic, and industrial quarters, whereas, site II was characterized by a sandy area with small rocks including desert plants with high temperature, a cement plant, and vehicle maintenance workshops. 


\subsection{Samples Collection and Examination}

A total of 100 individuals for all castes of the harvester termite Anacanthotermes ochraceus were randomly collected from indexed wood and sand of two distinct natural habitats in Saudi Arabia. After collection, the samples were transported immediately to the Laboratory of Entomology Research, College of Science, King Saud University, Riyadh, Saudi Arabia, for further investigations. The termite specimens were collected in plastic vials with $70 \%$ ethyl alcohol; several were studied under stereoscopic binocular microscope. The collected termites were identified based on their external morphological characteristics, such as shape and size of the head, labrum, mandibles, pronotum, postmentum, and position of the tooth and antennal segments, etc., according to Badawi et al. [25].

\subsection{Molecular Analysis}

DNA was extracted from the ethanol-preserved specimens using the DNeasy Tissue Kit (Qiagen, Hilden, Germany) in accordance with the manufacturer's instructions. The PCR amplification of a $5^{\prime}$ portion of the $12 \mathrm{~S}$ rRNA was carried out using the termite-specific primers 12S-F (SR-J-14199) 5'-TAC TAT GTT ACG ACT TAT-3' and 12S-R (SR-N-14594) 5'-AAA CTA GGA TTA GAT ACC C-3' designed by Murthy et al. [26]. Each reaction mixture of $25 \mu \mathrm{L}$ consisted of $2.5 \mu \mathrm{L}$ of $10 \times$ PCR buffer, $2.0 \mu \mathrm{L} \mathrm{MgCl}_{2}(2.5 \mathrm{mM}), 0.2 \mu \mathrm{L}$ dNTPs $(200 \mu \mathrm{M}), 1 \mu \mathrm{L}$ of Taq Polymerase $(1 \mathrm{U} / \mu \mathrm{L}), 1 \mu \mathrm{L}$ of each primer, $1 \mu \mathrm{L}$ of extracted DNA, and $16.3 \mu \mathrm{L}$ of distilled $\mathrm{H}_{2} \mathrm{O}$. The PCR program included an initial denaturation at $94{ }^{\circ} \mathrm{C}$ for $15 \mathrm{~min}$, followed by 45 cycles of denaturation at $94{ }^{\circ} \mathrm{C}$ for $45 \mathrm{~s}$, annealing at $41{ }^{\circ} \mathrm{C}$ for $45 \mathrm{~s}$, extension at $72{ }^{\circ} \mathrm{C}$ for $45 \mathrm{~s}$, and a final extension at $72{ }^{\circ} \mathrm{C}$ for $10 \mathrm{~min}$. The amplified DNA fragments were separated on $2.5 \%$ agarose gel in $1 \times$ Tris-acetate-EDTA (TAE) (stained with $1 \%$ ethidium bromide) with a DNA ladder (100 bp) (Solis Biodyne, Tartu, Estonia). PCR products were visualized on a UV trans-illuminator and photographed using a gel documentation system (Image Analyzer, Malvern, UK). The PCR products were purified via Montage PCR96 Cleanup Kit (Milliopore, Darmstadt, Germany) and then sequenced using ABI BigDye 3.1®Sequencing Kit on an ABI 310 Automated DNA Sequencer (Applied Biosystems, Midland, ON, Canada). Reading frames were identified using the basic local alignment search tool (BLAST) searches (blastx) [27] as implemented by the National Center for Biotechnology Information (NCBI) website. The sequences of all termite species were aligned and compared with the species obtained from PUBMED using CLUSTAL-X multiple sequence alignment [28] (Table 1). Gaps were treated as missing characters in all sequence alignments. A phylogenetic tree was tested by applying a bootstrap test [29]. A phylogenetic tree was constructed using the character-based maximum-likelihood method based on the Tamura-Nei model [30]. The nodal support values among branches were assessed through a bootstrap analysis with 1000 replicates. The constructed phylogenetic tree was visualized using MEGA ver.6 [31]. The tree was drawn to scale, with branch lengths in the same units as those of the evolutionary distances used to infer the phylogenetic tree. 
Table 1. Termitid species used in the phylogenetic analysis of the present $A$. ochraceus.

\begin{tabular}{|c|c|c|c|c|c|}
\hline Parasite Species & Order/Family & Source & Accession No. & $\begin{array}{l}\text { Sequence } \\
\text { Length (bp) }\end{array}$ & $\begin{array}{l}\text { Percent } \\
\text { Identity }(\%)\end{array}$ \\
\hline Cryptotermes secundus & Blattodea/Kalotermitidae & GenBank & DQ441676.1 & 407 & 80 \\
\hline Heterotermes tenuis & Blattodea/Rhinotermitidae & GenBank & DQ441706.1 & 416 & 81 \\
\hline Psammotermes voeltzkowi & Blattodea/Rhinotermitidae & GenBank & DQ441804.1 & 417 & 83 \\
\hline Prorhinotermes canalifrons & Blattodea/Rhinotermitidae & GenBank & EU253713.1 & 365 & 83 \\
\hline Pseudacanthotermes militaris & Blattodea/Termitidae & GenBank & DQ441805.1 & 413 & 84 \\
\hline Nasutitermes takasagoensis & Blattodea/Termitidae & GenBank & AB006588.1 & 404 & 82 \\
\hline Dolichorhinotermes longilabius & Blattodea/Rhinotermitidae & GenBank & DQ441686.1 & 415 & 83 \\
\hline Rhinotermes marginalis & Blattodea/Rhinotermitidae & GenBank & EU253715.1 & 359 & 83 \\
\hline Schedorhinotermes medioobscurus & Blattodea/Rhinotermitidae & GenBank & DQ441812.1 & 414 & 83 \\
\hline Schedorhinotermes lamanianus & Blattodea/Rhinotermitidae & GenBank & DQ441811.1 & 413 & 83 \\
\hline Schedorhinotermes putorius & Blattodea/Rhinotermitidae & GenBank & DQ441813.1 & 392 & 83 \\
\hline Microhodotermes viator & Blattodea/Hodotermitidae & GenBank & DQ441739.1 & 409 & 93 \\
\hline Microhodotermes viator & Blattodea/Hodotermitidae & GenBank & EU253701.1 & 360 & 93 \\
\hline Hodotermes mossambicus & Blattodea/Hodotermitidae & GenBank & MF554678.1 & 333 & 90 \\
\hline Anacanthotermes ochraceus & Blattodea/Hodotermitidae & GenBank & DQ441629.1 & 414 & 99 \\
\hline Archotermopsis wroughtoni & Blattodea/Termopsidae & GenBank & DQ441642.1 & 406 & 82 \\
\hline Zootermopsis angusticollis & Blattodea/Termopsidae & GenBank & DQ441841.1 & 405 & 88 \\
\hline Stolotermes inopinus & Blattodea/Termopsidae & GenBank & DQ̂441818.1 & 414 & 82 \\
\hline Porotermes quadricollis & Blattodea/Termopsidae & GenBank & DQ441794.1 & 406 & 87 \\
\hline Mastotermes darwiniensis & Blattodea/Mastotermitidae & GenBank & EF623330.1 & 400 & 85 \\
\hline Reticulitermes tibialis & Blattodea/Rhinotermitidae & GenBank & AY168221.1 & 441 & 83 \\
\hline
\end{tabular}

\subsection{Chemical Analysis for Measuring Heavy Metals}

The metal content of the whole termite bodies and soil samples was quantified. Termite tissues were cleaned by washing with double distilled $\mathrm{H}_{2} \mathrm{O}$. Soil samples were collected within $1 \mathrm{~m}$ from each termite colony in two sites under investigation. Soil samples were obtained by removing a $15 \times 15 \mathrm{~cm}$ portion of soil to a depth approximately $10 \mathrm{~cm}$, and then crushed with a wooden pestle and mortar to pass through a $2 \mathrm{~mm}$ pore sieve. Termite and soil samples were dried in oven at $105^{\circ} \mathrm{C}$ for $6-12 \mathrm{~h}$, and then weighed using a microbalance. The metal content was determined by digesting $0.5 \mathrm{~g}$ of the oven-dried material in $5 \mathrm{~mL} \mathrm{HNO}$ at $550{ }^{\circ} \mathrm{C}$ for $6-12 \mathrm{~h}$, after which $2 \mathrm{~mL}$ of $\mathrm{HClO}_{4}$ was added and the volume adjusted to $10 \mathrm{~mL}$ with deionized $\mathrm{H}_{2} \mathrm{O}$. Concentration of elements was performed using an inductively coupled plasma-optical emission spectroscopy (ICP-OES Varian 720/730-ES Series Spectrometers). All metals were determined and expressed as $\mathrm{mg} / \mathrm{g}$ dry weight. The absorption wavelengths and detection limits for the heavy metals were $396.152 \mathrm{~nm}$ and $0.12 \mathrm{ppm}$ for $\mathrm{Al}, 313.042 \mathrm{~nm}$ and $0.05 \mathrm{ppm}$ for Be, $455.403 \mathrm{~nm}$ and $0.16 \mathrm{ppm}$ for $\mathrm{Ba}, 315.887 \mathrm{~nm}$ and $1.05 \mathrm{ppm}$ for $\mathrm{Ca}, 214.439 \mathrm{~nm}$ and $0.04 \mathrm{ppm}$ for $\mathrm{Cd}, 238.892 \mathrm{~nm}$ and $0.02 \mathrm{ppm}$ for $\mathrm{Co}, 267.716 \mathrm{~nm}$ and $0.04 \mathrm{ppm}$ for $\mathrm{Cr}, 327.395 \mathrm{~nm}$ and $0.05 \mathrm{ppm}$ for $\mathrm{Cu}, 238.204 \mathrm{~nm}$ and $0.01 \mathrm{ppm}$ for $\mathrm{Fe}, 279.553 \mathrm{~nm}$ and $0.01 \mathrm{ppm}$ for $\mathrm{Mg}, 257.610 \mathrm{~nm}$ and $0.05 \mathrm{ppm}$ for $\mathrm{Mn}, 202.032 \mathrm{~nm}$ and $0.05 \mathrm{ppm}$ for Mo, $231.604 \mathrm{~nm}$ and $0.001 \mathrm{ppm}$ for $\mathrm{Ni}, 220.353 \mathrm{~nm}$ and $0.13 \mathrm{ppm}$ for $\mathrm{Pb}, 306.772 \mathrm{~nm}$ and $0.02 \mathrm{ppm}$ for $\mathrm{V}$, and $213.857 \mathrm{~nm}$ and $0.04 \mathrm{ppm}$ for $\mathrm{Zn}$, respectively.

The contamination factor (CF) for soil was determined according to Håkanson [32] as follows: CF $=\mathrm{C}_{\text {Heavy metal }} / \mathrm{C}_{\text {Background, }}$, the " $\mathrm{CF}<1$ " values indicate low contamination; the " $1<\mathrm{CF}<3$ " values indicate moderate contamination; the " $3<\mathrm{CF}<6$ " values indicate considerable contamination; and the "CF $>6$ " values indicate very high contamination. The pollution load index (PLI) was used in order to compare the total content of heavy metals at the studied sites according to Usero et al. [33] as follows: $\mathrm{PLI}=\left(\mathrm{CF} 1^{*} \mathrm{CF} 2{ }^{*} \mathrm{CF}^{*} \ldots \ldots{ }^{*} \mathrm{CF}_{\mathrm{n}}\right)^{1 / n} . \mathrm{N}$ is the number of metals; $\mathrm{CF}$ is the contamination factor; $\mathrm{PLI}=0$ indicates perfection; PLI $=1$ indicates the presence of only baseline levels of pollutants; PLI > 1 indicates the progressive deterioration of the site quality. To determine the sum of all contamination factors for a given site, the degree of contamination (DC) was calculated as follows: DC $=\sum_{i=1}^{n} \mathrm{CFi}$. CF: 
represents a single contamination factor; $n$ : indicates the count of the elements present at a site; $D C<n$ indicates low degree of contamination; $\mathrm{n} \leq \mathrm{DC}<2 \mathrm{n}$ indicates moderate degree of contamination; $2 \mathrm{n} \leq \mathrm{DC}<4 \mathrm{n}$ indicates considerable degree of contamination; $\mathrm{DC}>4 \mathrm{n}$ indicates very high degree of contamination. To express the accumulation capacity of termites, the ratios of $C_{\text {[termite] }} / C_{\text {[soil] }}$ (Bioconcentration factors, BCF) (bioaccumulation was considered, when the values of BCF $\geq 1$ ) were calculated according to Sures et al. [34]. Additionally, the concentration ratio between the termites in Site I to those in Site II was determined.

\subsection{Statistical Analysis}

All data obtained from the experiment were presented as mean $\pm \mathrm{SE}$ and subjected to the one-way analysis of variance test (ANOVA) from which the significant relationships between the accumulation of heavy metals in termites and their inhabited sites were established. All statistical procedures were performed with the SPSS statistics 16.0 software (SPSS Inc., Chicago, IL, USA). The differences were considered significant, when the $p$-values were $\leq 0.01$ and $\leq 0.05$. In addition, the Pearson's correlation coefficients ( $r$ ) were calculated to check the possible relationship/interactions between the heavy metal concentrations in different localities and their samples.

\section{Results}

The termite samples were collected from two different sites (I and II) in Saudi Arabia. A. ochraceus soldiers were identified as the most abundant species across the two study sites. It was morphologically characterized by a shiny body covered with tiny hairs, oblong head capsule (mean length $0.4 \mathrm{~mm}$ and width $0.3 \mathrm{~mm}$ ) and curved posterior margin. Eyes were black and small. Mandibles were well serrated and asymmetric in length (the left one was $0.5 \mathrm{~mm}$ and the right one was $0.3 \mathrm{~mm}$ ). Antenna consisted of 25 segments. Thorax and legs were yellowish and developed. The pronotum was broad and the abdomen was white in color.

\subsection{Molecular Analysis}

A sequence of $407 \mathrm{bp}$ was deposited in GenBank (gb I MG197798.1) with 34.2\% GC content for the partial 12S rRNA gene sequences of the present hodotermitid species. A pairwise comparison of the isolated genomic sequence of the present termite species with a range of other isopteran species and genotypes revealed a unique genetic sequence. Calculating the percentage of identity between this novel genetic sequence and the other sequences retrieved from the GenBank demonstrated a high degree of similarity up to $80.0 \%$. A comparison of the nucleotide sequences and divergence showed that $12 \mathrm{~S}$ rRNA of the present species revealed the highest blast scores with lower divergence values for A. ochraceus (gb | DQ441629.1), Microhodotermes viator (gb | EU253701.1, DQ441739.1), Hodotermopsis sjostedti (gb|DQ441708.1), Hodotermes mossambicus (gb|MF554678.1), Zootermopsis angusticollis (gb I DQ441841.1), Mastotermes darwiniensis (gb I EF623330.1), Archotermopsis wroughtoni (gb | DQ441642.1), and Porotermes quadricollis (gb I DQ441794.1) (Figure 1). For estimating maximum likelihood (ML) values, a tree topology was automatically computed. The constructed dendrogram supports the suprafamilial termite lineages of Euisoptera and Neoisoptera, a later derived Kalotermitidae as a sister group of the Neoisoptera and a monophyletic clade of the dampwood (Stolotermitidae, Archotermopsidae) and harvester termites (Hodotermitidae) with strong support values (Figure 2). Within the Neoisoptera, Rhinotermitidae is consistently paraphyletic with respect to Termitidae, and Rhinotermitinae (represented by Schedorhinotermes) acts as a sister group to the remaining rhinotermitids plus termitids. Monotypic family Serritermitidae is nested within Rhinotermitidae. Serritermitidae is recovered as sister group to Rhinotermitidae and Termitidae. The resolution within Termitidae consistently supported Mastotermitidae as a sister group of the remaining termites (=Euisoptera), while there is support for the monophyletic Termitinae (i.e., Drepanotermes and Macrognathotermes) to the exclusion of Nasutitermes (Nasutitermitinae). The nodal supports were very high for the family-level relationships in termites. In addition, Hodotermitidae was recovered as a 
monophyletic group with the three genera of Anacanthotermes, Hodotermes, and Microhodotermes having nodal strong support values. The present sequence in conjunction with the existing data investigates the placement of this hodotermitid species within the infraorder Isoptera within order Blattodea. It was shown that the present species is deeply embedded in the genus Anacanthotermes in the same taxon with the previously described A. ochraceus.

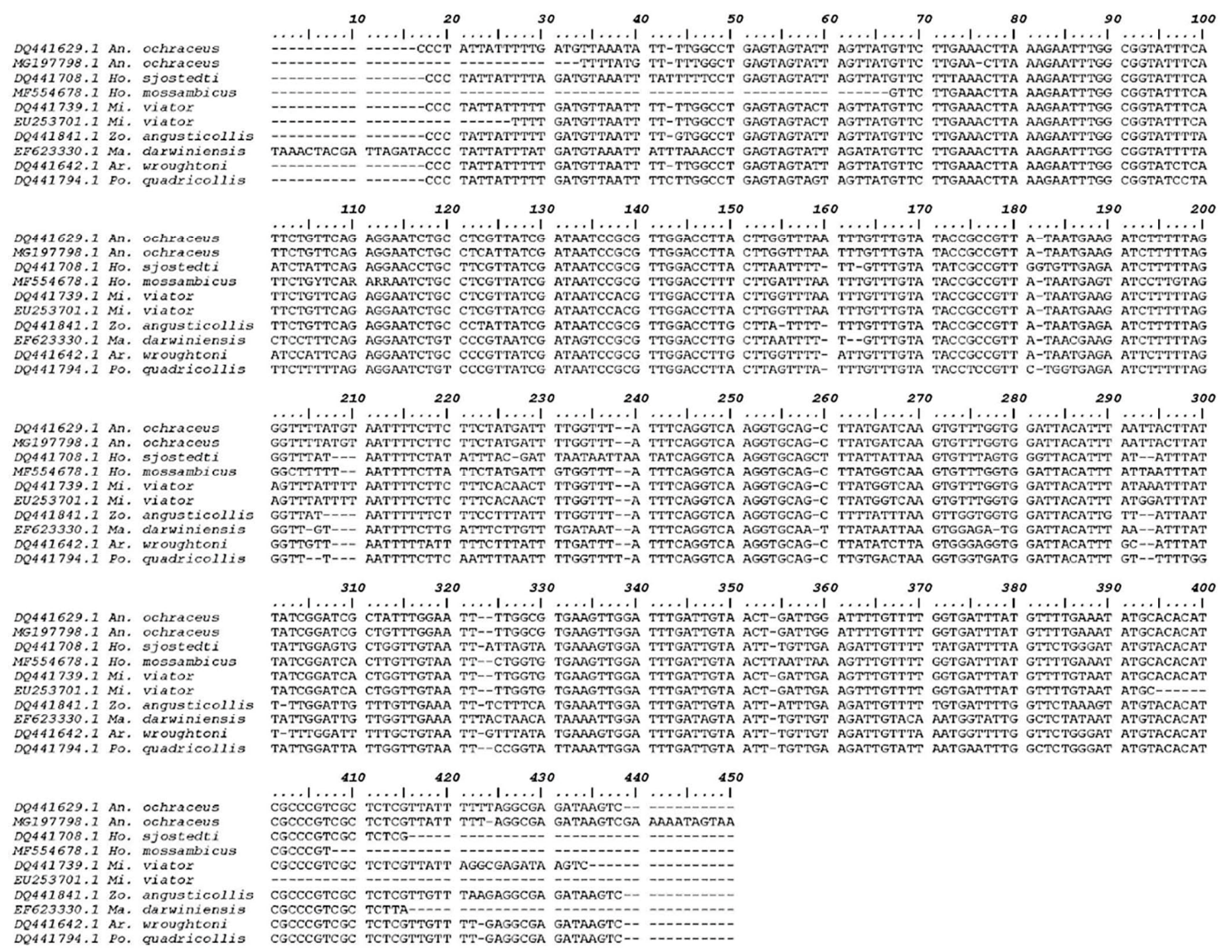

Figure 1. Sequence alignment of the $12 \mathrm{~S}$ rRNA of $A$. ochraceus with the most related species (Only variable sites are shown. Dots represent the bases identical to those of the first sequences, and dashes indicate gaps). 


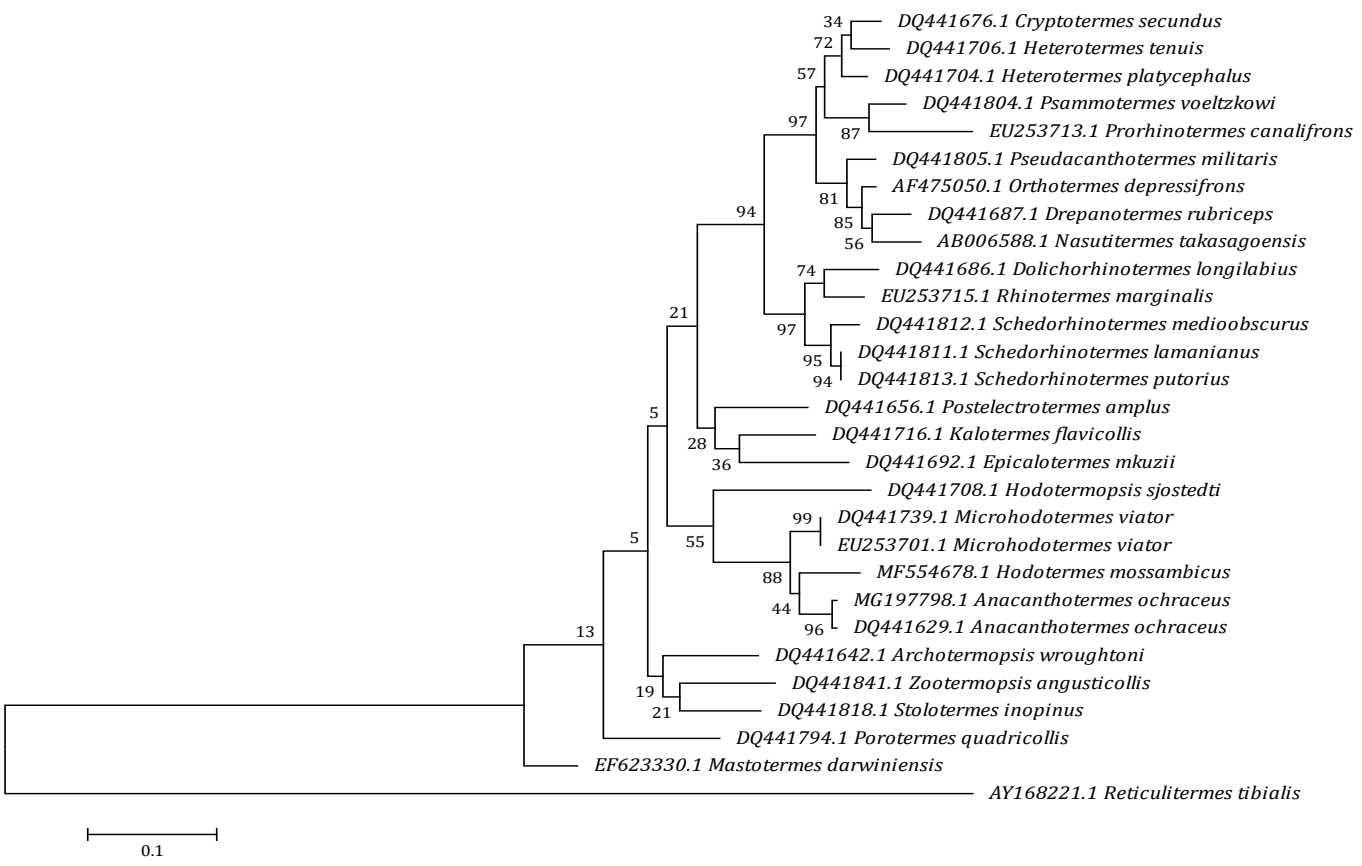

Figure 2. Molecular phylogenetic analysis by maximum likelihood based on the Tamura-Nei model. The tree with the highest log likelihood -2940.2934) is shown. The percentage of trees in which the associated taxa clustered together is shown next to the branches. The initial tree(s) for the heuristic search were obtained automatically by applying the Neighbor-Join and BioNJ algorithms to a matrix of pairwise distances estimated using the maximum composite likelihood (MCL) approach, and then selecting the topology with superior log likelihood value.

\subsection{Chemical Analysis}

The metal concentrations in the soil and termites collected from sites (I) and (II) in Saudi Arabia are shown in Table 2. All examined samples contained high concentrations of metals. Mean concentrations of the measured metals in soil samples were: $\mathrm{Ca}>\mathrm{Al}>\mathrm{Mg}>\mathrm{Zn}>\mathrm{Fe}>\mathrm{Cu}>\mathrm{Mn}>\mathrm{Ba}>\mathrm{Cr}$ $>\mathrm{Co}>\mathrm{Be}>\mathrm{Ni}>\mathrm{V}>\mathrm{Pb}>\mathrm{Cd}>\mathrm{Mo}$. Generally, the most measured metals had a significantly high concentration at Site II, except for $\mathrm{Ca}, \mathrm{Cd}, \mathrm{Co}, \mathrm{Cr}, \mathrm{Cu}, \mathrm{Mg}$, and $\mathrm{Ni}$, which had significantly high concentration at Site I. Some toxic elements $(\mathrm{Cd}, \mathrm{Co}$, and $\mathrm{Mo})$ were detected at concentrations lower than $0.5 \mathrm{mg} / \mathrm{g}$. Moderate concentrations were recorded for $\mathrm{Be}, \mathrm{Ba}, \mathrm{Cr}, \mathrm{Cu}, \mathrm{Mn}, \mathrm{Ni}, \mathrm{Pb}$, and $\mathrm{V}$, whereas the essential elements of $\mathrm{Al}, \mathrm{Ca}, \mathrm{Fe}, \mathrm{Mg}$, and $\mathrm{Zn}$ were found exceed $50 \mathrm{mg} / \mathrm{g}$.

Termites accumulated high amounts of heavy metals (Table 2). The order of metal concentrations in termites was $\mathrm{Ca}>\mathrm{Mg}>\mathrm{Al}>\mathrm{Fe}>\mathrm{Zn}>\mathrm{Cu}>\mathrm{Mn}>\mathrm{Be}>\mathrm{Ba}>\mathrm{Pb}>\mathrm{Cr}>\mathrm{V}>\mathrm{Ni}>\mathrm{Cd}>\mathrm{Mo}>$ $\mathrm{Co}$. The highest concentrations of $\mathrm{Ba}, \mathrm{Al}, \mathrm{Cr}, \mathrm{Fe}, \mathrm{Ni}, \mathrm{V}$, and $\mathrm{Zn}$ were found in the termites inhabiting Site II. While, the elements $\mathrm{Be}, \mathrm{Ca}, \mathrm{Cu}, \mathrm{Mg}, \mathrm{Mn}$, and $\mathrm{Pb}$ were found to accumulate to a significantly high degree in Site I. Among metals, the concentration of calcium was found to be the highest, whereas that of Co was the lowest in both soil samples and termites. When comparing the termite and soil metal content, the concentration of a metal within the termite bodies of Site II was always significantly correlated with the amount in the soil, except for $\mathrm{Co}$, which had the highest concentration in the soil samples of Site I as shown in Table 2. The biggest difference involved $\mathrm{Al}, \mathrm{Ca}, \mathrm{Cu}, \mathrm{Fe}$, and $\mathrm{Mg}$, where more than four-fold difference was observed in both soil samples and termites. 
Table 2. Heavy metal concentrations (mg/g dry weight) in two different habitats and tissues of $A$. ochraceus.

\begin{tabular}{|c|c|c|c|c|}
\hline \multirow{2}{*}{ Heavy Metal } & \multirow{2}{*}{$\begin{array}{c}\text { Soil Samples from Site } \\
\text { I (Riyadh) }\end{array}$} & \multirow{2}{*}{$\begin{array}{c}\text { Soil Samples from Site } \\
\text { II (Taif) }\end{array}$} & \multicolumn{2}{|c|}{ Anacanthotermes ochraceus } \\
\hline & & & Site I (Riyadh) & Site II (Taif) \\
\hline $\mathrm{Al}$ & $196.0533 \pm 32.90069^{c}$ & $378.4967 \pm 57.72633^{b c}$ & $961.9387 \pm 75.84870$ ab & $1514.1020 \pm 406.63030^{a}$ \\
\hline $\mathrm{Be}$ & $0.4422 \pm 0.07197^{b}$ & $0.3940 \pm 0.11393^{b}$ & $12.1700 \pm 3.09869 \mathrm{ab}$ & $6.3833 \pm 1.88832^{\mathrm{a}}$ \\
\hline $\mathrm{Ba}$ & $2.4420 \pm 1.08289^{b}$ & $4.1214 \pm 1.45522^{\mathrm{ab}}$ & $6.8607 \pm 1.92336^{\mathrm{ab}}$ & $8.9527 \pm 2.59292^{\mathrm{a}}$ \\
\hline $\mathrm{Ca}$ & $883.5467 \pm 101.56333^{b}$ & $455.5233 \pm 88.38769^{b}$ & $9625.6327 \pm 2672.88999^{a}$ & $4835.3907 \pm 1277.84243^{a b}$ \\
\hline $\mathrm{Cd}$ & $0.1060 \pm 0.2784^{\mathrm{b}}$ & $0.0847 \pm 0.2207^{\mathrm{b}}$ & $0.4533 \pm 0.10056^{a}$ & $0.3529 \pm 0.09159^{a}$ \\
\hline Co & $0.519 \pm 0.01354^{b}$ & $0.0264 \pm 0.00968^{b}$ & $0.2793 \pm 0.09498^{b}$ & $0.4573 \pm 0.18576^{\mathrm{a}}$ \\
\hline $\mathrm{Cr}$ & $0.6619 \pm 0.29671^{b}$ & $0.2162 \pm 0.09240^{b}$ & $2.1513 \pm 0.58658^{a b}$ & $2.8853 \pm 0.94224^{\mathrm{a}}$ \\
\hline $\mathrm{Cu}$ & $3.0313 \pm 0.84077^{b}$ & $2.8978 \pm 0.61136^{\mathrm{b}}$ & $42.7720 \pm 14.69708^{a b}$ & $23.2357 \pm 5.94914^{\mathrm{a}}$ \\
\hline $\mathrm{Fe}$ & $26.2683 \pm 6.97426^{b}$ & $32.3260 \pm 8.31177^{b}$ & $441.7793 \pm 138.77551^{b}$ & $940.9813 \pm 250.35349^{a}$ \\
\hline $\mathrm{Mg}$ & $65.3030 \pm 8.54049^{b}$ & $26.6207 \pm 6.22629^{b}$ & $2009.0593 \pm 523.75384^{a}$ & $1656.1273 \pm 428.84791^{a}$ \\
\hline $\mathrm{Mn}$ & $2.8454 \pm 1.15156^{b}$ & $6.3062 \pm 1.31417^{b}$ & $14.6213 \pm 3.97113^{\mathrm{ab}}$ & $11.5678 \pm 2.76065^{\mathrm{a}}$ \\
\hline Mo & $0.0383 \pm 0.01091^{b}$ & $0.475 \pm 0.01586^{b}$ & $0.4327 \pm 0.18244^{\mathrm{a}}$ & $0.4313 \pm 0.13122^{a}$ \\
\hline $\mathrm{Ni}$ & $0.2883 \pm 0.07573^{b}$ & $0.1363 \pm 0.04804^{b}$ & $1.5987 \pm 0.41954^{\mathrm{a}}$ & $2.0727 \pm 0.57519^{\mathrm{a}}$ \\
\hline $\mathrm{Pb}$ & $0.1553 \pm 0.07672^{b}$ & $0.2074 \pm 0.07582^{b}$ & $3.0707 \pm 0.78007^{\mathrm{a}}$ & $2.6593 \pm 0.66487^{a}$ \\
\hline $\mathrm{V}$ & $0.2692 \pm 0.07972^{\mathrm{b}}$ & $0.3537 \pm 0.11612^{b}$ & $1.6913 \pm 0.42388^{a}$ & $2.2733 \pm 0.59009^{a}$ \\
\hline $\mathrm{Zn}$ & $42.4307 \pm 7.21991^{b}$ & $89.7970 \pm 9.78533^{a b}$ & $124.9000 \pm 31.53582^{a b}$ & $185.1847 \pm 48.74656^{\mathrm{a}}$ \\
\hline
\end{tabular}

Mean values within the same row with different superscripts differ significantly at $p \leq 0.05$.

The CF of heavy metals in the soil samples of Site I (Table 3) represented two categories of contamination as moderate $\mathrm{CF}(1<\mathrm{CF}<3)$ varying from 1.1946 to 2.6501 for $\mathrm{Be}, \mathrm{Cd}$, and $\mathrm{Pb}$; and high $\mathrm{CF}(\mathrm{CF}>3)$ varying from 4.7661 to 66530.3 for $\mathrm{Al}, \mathrm{Ba}, \mathrm{Ca}, \mathrm{Co}, \mathrm{Cr}, \mathrm{Cu}, \mathrm{Fe}, \mathrm{Mg}, \mathrm{Mn}, \mathrm{Mo}, \mathrm{Ni}, \mathrm{V}$, and $\mathrm{Zn}$. The sequence of $\mathrm{CF}$ for heavy metals in the soil of Riyadh in this region was: $\mathrm{Mg}>\mathrm{Fe}>\mathrm{Al}>\mathrm{Zn}>$ $\mathrm{Ca}>\mathrm{Ni}>\mathrm{Cu}>\mathrm{Mn}>\mathrm{Co}>\mathrm{Cr}>\mathrm{Ba}>\mathrm{V}>\mathrm{Mo}>\mathrm{Cd}>\mathrm{Be}>\mathrm{Pb}$. This sequence shows that $\mathrm{Mg}$ is the most abundant metal, whereas $\mathrm{Pb}$ showed the lowest appearance. In addition, Site II represented two categories of contamination as moderate $\mathrm{CF}(1<\mathrm{CF}<3)$ varying from 1.3242 to $1.9701 \mathrm{for} \mathrm{Be}, \mathrm{Cd}, \mathrm{Co}$, and $\mathrm{Pb}$; and high $\mathrm{CF}(\mathrm{CF}>3)$ varying from 5.4052 to 3232.6 for $\mathrm{Al}, \mathrm{Ba}, \mathrm{Ca}, \mathrm{Cr}, \mathrm{Cu}, \mathrm{Fe}, \mathrm{Mg}, \mathrm{Mn}, \mathrm{Mo}, \mathrm{Ni}$, $\mathrm{V}$, and $\mathrm{Zn}$. The descending sequence of $\mathrm{CF}$ for metals in the soil of Site II was: $\mathrm{Fe}>\mathrm{Al}>\mathrm{Mg}>\mathrm{Zn}>\mathrm{Ca}$ $>\mathrm{Ni}>\mathrm{Mn}>\mathrm{Cu}>\mathrm{Ba}>\mathrm{Mo}>\mathrm{V}>\mathrm{Cr}>\mathrm{Cd}>\mathrm{Be}>\mathrm{Pb}>\mathrm{Co}$, showing that $\mathrm{Fe}$ is the most abundant metal; whereas $\mathrm{Co}$ showed the lowest appearance.

Table 3. Contamination factor, pollution load index, and degree of contamination of soil and $A$. ochraceus samples from two sites (I, II).

\begin{tabular}{|c|c|c|c|c|c|c|}
\hline \multirow{2}{*}{ Heavy Metals } & \multicolumn{2}{|c|}{ Contamination Factor (CF) } & \multicolumn{2}{|c|}{ Pollution Load Index (PLI) } & \multicolumn{2}{|c|}{ Degree of Contamination (DC) } \\
\hline & Site I & Site II & Site I & Site II & Site I & Site II \\
\hline $\mathrm{Al}$ & 1633.7 & 3154.1 & 0.7648 & 1.0632 & 4876.3 & 9765.2 \\
\hline $\mathrm{Be}$ & 2.2113 & 1.9701 & 0.2778 & 0.3923 & 6.2453 & 5.7873 \\
\hline $\mathrm{Ba}$ & 15.262 & 25.758 & 0.8440 & 0.1756 & 45.785 & 76.256 \\
\hline $\mathrm{Ca}$ & 883.35 & 455.52 & 0.4402 & 0.3170 & 2576.2 & 1298.6 \\
\hline $\mathrm{Cd}$ & 2.6501 & 2.1175 & 0.1610 & 0.3159 & 7.9343 & 6.0549 \\
\hline Co & 25.951 & 1.3242 & 0.1717 & 1.2919 & 75.987 & 3.6757 \\
\hline $\mathrm{Cr}$ & 16.547 & 5.4052 & 0.6619 & 0.1899 & 43.765 & 13.657 \\
\hline $\mathrm{Cu}$ & 60.626 & 57.956 & 0.1346 & 0.1541 & 175.76 & 169.65 \\
\hline $\mathrm{Fe}$ & 2626.8 & 3232.6 & 1.6551 & 8.8810 & 7545.6 & 9654.7 \\
\hline $\mathrm{Mg}$ & 6530.3 & 2662.1 & 1.0747 & 1.5895 & 18545.2 & 7644.5 \\
\hline $\mathrm{Mn}$ & 56.908 & 126.12 & 0.1628 & 0.1495 & 165.87 & 325.54 \\
\hline Mo & 4.7661 & 9.5202 & 0.0277 & 0.0347 & 2.0857 & 26.549 \\
\hline $\mathrm{Ni}$ & 288.32 & 136.30 & 0.1252 & 0.1183 & 765.98 & 389.98 \\
\hline $\mathrm{Pb}$ & 1.1946 & 1.5953 & 1.7578 & 0.7389 & 3.4598 & 4.2983 \\
\hline $\mathrm{V}$ & 5.3842 & 7.0743 & 0.0192 & 0.0847 & 15.986 & 20.765 \\
\hline $\mathrm{Zn}$ & 1060.7 & 2244.9 & 1.2509 & 2.6525 & 3058.4 & 6375.6 \\
\hline
\end{tabular}

The PLI and degree of contamination (DC) of heavy metals in the soil samples from the two studied sites are shown in Table 3. The PLI of Site (I) ranged between 0.0192 and 1.7578 and showed a 
progressive deterioration of site quality. The contamination degree in Site I indicates a considerable degree of pollution. The PLI of Site II ranged between 0.0347 and 2.6525.

According to the bioconcentration factors, termites showed the highest accumulation rates up to 50.377 for all recorded elements as shown in Table 4. The comparison of element concentration in termites between the two sites (I, II) revealed a clear difference. Accordingly, the $\mathrm{C}_{[\text {A. ochraceus Site I] }} / \mathrm{C}_{\text {[A. ochraceus Site II] }}$ ratios for the most essential elements were higher than 0.5, with the following order $\mathrm{Ca}>\mathrm{Be}>\mathrm{Cu}>\mathrm{Mo}>\mathrm{Cd}>\mathrm{Mg}>\mathrm{Pb}>\mathrm{Ni}>\mathrm{Ba}>\mathrm{Cr}>\mathrm{V}>\mathrm{Zn}>\mathrm{Mn}>\mathrm{Fe}$ $>\mathrm{Co}>\mathrm{Al}$.

Table 4. Estimates of the accumulation capacity and bioconcentration factors (BCF)

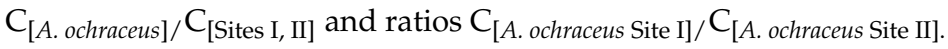

\begin{tabular}{cccc}
\hline Heavy Metals & $\mathrm{C}_{[\text {A. ochraceus }]} \mathrm{C}_{[\text {Site I }]}$ & $\mathrm{C}_{[\text {A. ochraceus }]} \mathbf{C}_{[\text {Site II] }}$ & $\mathrm{C}_{[\text {A. ochraceus Site I }] / \mathbf{C}_{[\text {A. ochraceus Site II] }}}$ \\
\hline $\mathrm{Al}$ & 5.1183 & 3.4995 & 0.5222 \\
$\mathrm{Be}$ & 28.290 & 19.088 & 1.9065 \\
$\mathrm{Ba}$ & 3.3319 & 2.5774 & 0.7663 \\
$\mathrm{Ca}$ & 10.611 & 8.9935 & 1.9906 \\
$\mathrm{Cd}$ & 2.7169 & 2.5480 & 1.2519 \\
$\mathrm{Co}$ & 6.4979 & 26.032 & 0.5249 \\
$\mathrm{Cr}$ & 2.5215 & 18.137 & 0.7456 \\
$\mathrm{Cu}$ & 22.586 & 7.3969 & 1.8408 \\
$\mathrm{Fe}$ & 17.825 & 27.608 & 0.5694 \\
$\mathrm{Mg}$ & 27.394 & 50.377 & 1.2131 \\
$\mathrm{Mn}$ & 4.5726 & 3.0160 & 0.6498 \\
$\mathrm{Mo}$ & 15.919 & 11.677 & 1.4667 \\
$\mathrm{Ni}$ & 5.9092 & 19.347 & 0.7713 \\
$\mathrm{~Pb}$ & 19.774 & 11.263 & 1.1546 \\
$\mathrm{~V}$ & 4.6089 & 6.1567 & 0.7439 \\
$\mathrm{Zn}$ & 2.0687 & 1.6891 & 0.6744 \\
\hline
\end{tabular}

The assessment of the overall relationship between the collected samples with heavy metal concentrations showed that most elements had weak to very strong correlation. Table 5 shows significant positive correlation of $\mathrm{Al}$ with $\mathrm{Mo}$ and $\mathrm{Pb}(\mathrm{r}=0.999$ and 1.000 , respectively) and a negative correlation with $\mathrm{Cr}(\mathrm{r}=-0.572)$. The metal Be showed a significant positive correlation with $\mathrm{Fe}$ $(\mathrm{r}=1.000)$ and a negative correlation with $\mathrm{Cr}(\mathrm{r}=-0.348)$. Ba showed a significant positive correlation with $\mathrm{Ca}(\mathrm{r}=1.000)$ and a negative correlation with $\mathrm{Cr}(\mathrm{r}=-0.244)$. Both $\mathrm{Ca}$ and $\mathrm{Cd}$ correlated negatively with $\mathrm{Cr}(\mathrm{r}=-0.228$ and -0.645 , respectively). Co correlated negatively with $\mathrm{Mg}$ and $\mathrm{V}$ $(\mathrm{r}=-0.446$ and -0.483 , respectively). Cr showed a negative correlation with $\mathrm{Cu}, \mathrm{Fe}, \mathrm{Mg}, \mathrm{Mn}, \mathrm{Mo}, \mathrm{Ni}$, and $\mathrm{Pb}(\mathrm{r}=-0.434,-0.340,-0.997,-0.503,-0.541,-0.499$, and -0.572 , respectively) and a positive correlation with $\mathrm{V}(\mathrm{r}=0.999)$. Cu showed significant positive correlation with $\mathrm{Mn}$ and $\mathrm{Ni}(\mathrm{r}=0.997)$. $\mathrm{Mg}$ showed significant positive correlation with $\mathrm{V}(\mathrm{r}=0.999)$, and Mn with Mo and Ni $(\mathrm{r}=0.999$ and 1.000 , respectively). Mo showed significant positive correlation with $\mathrm{Ni}$ and $\mathrm{Pb}(\mathrm{r}=0.999)$, whereas, $\mathrm{V}$ correlated negatively with $\mathrm{Zn}(\mathrm{r}=-0.307)$.

Table 6 shows a significant positive correlation between $\mathrm{Al}$ and $\mathrm{Cu}(\mathrm{r}=0.998)$ and a negative correlation between $\mathrm{Al}$ and $\mathrm{Cd}(\mathrm{r}=-0.875)$. Be had a significant positive correlation with $\mathrm{Ca}$ and $\mathrm{Fe}$ $(\mathrm{r}=1.000$ and 0.999 , respectively) and negative correlation with $\mathrm{Cd}(\mathrm{r}=-0.971)$. Ba and Ca correlated negatively with $\mathrm{Cd}(\mathrm{r}=-0.219$ and -0.975 , respectively), and $\mathrm{Cd}$ correlated negatively with $\mathrm{Co}, \mathrm{Cr}, \mathrm{Cu}$, $\mathrm{Fe}, \mathrm{Mg}, \mathrm{Mn}, \mathrm{Mo}, \mathrm{Ni}, \mathrm{Pb}$, and V $(\mathrm{r}=-0.998,-0.383,-0.905,-0.959,-0.996,-0.998,-1.000,-0.999$, -0.993 , and -0.832 , respectively). Co correlated positively with $\mathrm{Mg}, \mathrm{Mo}, \mathrm{Ni}$, and $\mathrm{Pb}(\mathrm{r}=1.000,0.997$, 1.000 , and 0.998 , respectively). Mg correlated significantly positively with $\mathrm{Ni}$ and $\mathrm{Pb}(\mathrm{r}=0.999$ and 1.000 , respectively), and Mn correlated Mo $(\mathrm{r}=0.999)$. Mo correlated significantly positively with $\mathrm{Ni}$ $(\mathrm{r}=0.998)$. Ni correlated positively with $\mathrm{Pb}(\mathrm{r}=0.998)$ and negatively with $\mathrm{Zn}(\mathrm{r}=-0.307)$. 
Table 5. Correlation between the concentrations of heavy metals in the soil samples of Site I (Riyadh).

\begin{tabular}{|c|c|c|c|c|c|c|c|c|c|c|c|c|c|c|c|c|}
\hline \multirow{2}{*}{ Variables } & \multicolumn{16}{|c|}{ Concentrations of Different Heavy Metals in Site I } \\
\hline & Al & Be & Ba & $\mathrm{Ca}$ & $\mathrm{Cd}$ & Co & $\mathrm{Cr}$ & $\mathrm{Cu}$ & $\mathrm{Fe}$ & $\mathrm{Mg}$ & Mn & Mo & $\mathrm{Ni}$ & $\mathrm{Pb}$ & $\mathbf{V}$ & $\mathrm{Zn}$ \\
\hline Al & 1 & & & & & & & & & & & & & & & \\
\hline Be & 0.968 & 1 & & & & & & & & & & & & & & \\
\hline Ba & 0.935 & 0.994 & 1 & & & & & & & & & & & & & \\
\hline $\mathrm{Ca}$ & 0.929 & 0.992 & $1.000 *$ & 1 & & & & & & & & & & & & \\
\hline $\mathrm{Cd}$ & 0.996 & 0.941 & 0.899 & 0.891 & 1 & & & & & & & & & & & \\
\hline Co & 0.406 & 0.623 & 0.704 & 0.716 & 0.321 & 1 & & & & & & & & & & \\
\hline $\mathrm{Cr}$ & -0.572 & -0.348 & -0.244 & -0.228 & -0.645 & 0.517 & 1 & & & & & & & & & \\
\hline $\mathrm{Cu}$ & 0.987 & 0.996 & 0.980 & 0.976 & 0.968 & 0.547 & -0.434 & 1 & & & & & & & & \\
\hline $\mathrm{Fe}$ & 0.966 & $1.000^{* *}$ & 0.995 & 0.993 & 0.938 & 0.629 & -0.340 & 0.995 & 1 & & & & & & & \\
\hline Mg & 0.636 & 0.422 & 0.321 & 0.305 & 0.704 & -0.446 & -0.997 & 0.505 & 0.415 & 1 & & & & & & \\
\hline Mn & 0.997 & 0.985 & 0.961 & 0.959 & 0.985 & 0.480 & -0.503 & $0.997 *$ & 0.984 & 0.570 & 1 & & & & & \\
\hline Mo & $0.999 *$ & 0.977 & 0.948 & 0.942 & 0.992 & 0.440 & -0.541 & 0.992 & 0.975 & 0.607 & $0.999 *$ & 1 & & & & \\
\hline $\mathrm{Ni}$ & 0.996 & 0.986 & 0.962 & 0.958 & 0.984 & 0.484 & -0.499 & 0.997 * & 0.985 & 0.567 & $1.000^{* *}$ & $0.999 *$ & 1 & & & \\
\hline $\mathbf{P b}$ & $1.000^{* *}$ & 0.968 & 0.935 & 0.929 & 0.996 & 0.407 & -0.572 & 0.987 & 0.966 & 0.636 & 0.997 & $0.999 *$ & 0.996 & 1 & & \\
\hline $\mathbf{V}$ & 0.604 & 0.384 & 0.281 & 0.266 & 0.674 & -0.483 & 0.999 * & 0.468 & 0.376 & $0.999 *$ & 0.536 & 0.573 & 0.532 & 0.603 & 1 & \\
\hline $\mathrm{Zn}$ & 0.574 & 0.761 & 0.827 & 0.836 & 0.497 & 0.981 & 0.343 & 0.697 & 0.766 & -0.267 & 0.639 & 0.604 & 0.642 & 0.574 & -0.307 & 1 \\
\hline
\end{tabular}

${ }^{*}$ Correlation is significant at the 0.05 level. ${ }^{* *}$ Correlation is significant at the 0.01 level. 
Table 6. Correlation between the concentrations of heavy metals in the soil samples of Site II (Taif).

\begin{tabular}{|c|c|c|c|c|c|c|c|c|c|c|c|c|c|c|c|c|}
\hline \multirow{2}{*}{ Variables } & \multicolumn{16}{|c|}{ Concentrations of Different Heavy Metals in Site I } \\
\hline & Al & Be & Ba & $\mathrm{Ca}$ & Cd & Co & $\mathrm{Cr}$ & $\mathrm{Cu}$ & $\mathrm{Fe}$ & Mg & Mn & Mo & $\mathrm{Ni}$ & $\mathrm{Pb}$ & $\mathbf{V}$ & $\mathrm{Zn}$ \\
\hline Al & 1 & & & & & & & & & & & & & & & \\
\hline Be & 0.965 & 1 & & & & & & & & & & & & & & \\
\hline Ва & 0.664 & 0.446 & 1 & & & & & & & & & & & & & \\
\hline $\mathrm{Ca}$ & 0.961 & $1.000 *$ & 0.432 & 1 & & & & & & & & & & & & \\
\hline $\mathrm{Cd}$ & -0.875 & -0.971 & -0.219 & -0.975 & 1 & & & & & & & & & & & \\
\hline Co & 0.902 & 0.984 & 0.277 & 0.986 & $-0.998 *$ & 1 & & & & & & & & & & \\
\hline $\mathrm{Cr}$ & 0.783 & 0.593 & 0.985 & 0.580 & -0.383 & 0.438 & 1 & & & & & & & & & \\
\hline $\mathrm{Cu}$ & $0.998^{*}$ & 0.981 & 0.613 & 0.977 & -0.905 & 0.929 & 0.739 & 1 & & & & & & & & \\
\hline $\mathrm{Fe}$ & 0.976 & $0.999^{*}$ & 0.487 & $0.998 *$ & -0.959 & 0.974 & 0.630 & 0.989 & 1 & & & & & & & \\
\hline Mg & 0.914 & 0.988 & 0.304 & 0.991 & -0.996 & $1.000 *$ & 0.463 & 0.939 & 0.980 & 1 & & & & & & \\
\hline Mn & 0.843 & 0.954 & 0.159 & 0.959 & $-0.998^{*}$ & 0.993 & 0.326 & 0.877 & 0.939 & 0.989 & 1 & & & & & \\
\hline Mo & 0.867 & 0.967 & 0.203 & 0.971 & $-1.000 *$ & $0.997 *$ & 0.368 & 0.898 & 0.954 & 0.995 & $0.999 *$ & 1 & & & & \\
\hline $\mathrm{Ni}$ & 0.900 & 0.982 & 0.272 & 0.985 & $-0.999 *$ & $1.000 * *$ & 0.433 & 0.927 & 0.973 & $0.999 *$ & 0.993 & $0.998 *$ & 1 & & & \\
\hline $\mathbf{P b}$ & 0.925 & 0.992 & 0.331 & 0.994 & -0.993 & 0.998 * & 0.487 & 0.948 & 0.985 & $1.000 *$ & 0.984 & 0.991 & 0.998 * & 1 & & \\
\hline $\mathbf{V}$ & 0.997 & 0.941 & 0.724 & 0.935 & -0.832 & 0.864 & 0.831 & 0.989 & 0.955 & 0.877 & 0.796 & 0.823 & 0.861 & 0.891 & 1 & \\
\hline $\mathrm{Zn}$ & -0.598 & -0.786 & 0.202 & -0.796 & 0.911 & -0.885 & 0.031 & -0.650 & -0.757 & -0.872 & -0.935 & -0.918 & -0.888 & -0.858 & -0.530 & 1 \\
\hline
\end{tabular}

${ }^{*}$ Correlation is significant at the 0.05 level. ${ }^{* *}$ Correlation is significant at the 0.01 level. 
Table 7 shows a significantly positive correlation of $\mathrm{Al}$ with $\mathrm{Cu}$ and $\mathrm{Zn}(\mathrm{r}=1.000)$. Be correlated positively with $\mathrm{Cd}$ and $\mathrm{Mn}(\mathrm{r}=0.999$ and 1.000 , respectively) and negatively with $\mathrm{Cr}$ and $\mathrm{Ni}(\mathrm{r}=-0.469$, -1.000 ; respectively). Ba correlated negatively with $\mathrm{Cr}$ and $\mathrm{Ni}(\mathrm{r}=-0.607$ and -0.984 , respectively). Ca correlated positively with $\mathrm{Mg}, \mathrm{Pb}$, and $\mathrm{V}(\mathrm{r}=0.998,0.998$, and 0.999 , respectively) and negatively with $\mathrm{Cr}$ and $\mathrm{Ni}(\mathrm{r}=-0.307$ and -0.987 , respectively). Cd correlated positively with $\mathrm{Mg}$ and $\mathrm{Mn}$ ( $\mathrm{r}=0.998$ and 0.999 , respectively) and negatively with $\mathrm{Cr}$ and $\mathrm{Ni}(\mathrm{r}=-0.435$ and -1.000 , respectively). Cr correlated negatively with $\mathrm{Co}, \mathrm{Mg}, \mathrm{Mn}, \mathrm{Pb}$, and V ( $\mathrm{r}=-0.709,-0.372,-0.471,-0.251$, and -0.256 , respectively). Fe correlated significant positively with $\mathrm{Mo}(\mathrm{r}=1.000)$ and negatively with $\mathrm{Ni}(\mathrm{r}=-0.635)$. A negative correlation was found between $\mathrm{Ni}$ and $\mathrm{Cu}, \mathrm{Co}, \mathrm{Mg}, \mathrm{Mn}, \mathrm{Mo}, \mathrm{Pb}$, and $\mathrm{V}(\mathrm{r}=-0.840,-0.951,-0.996,-1.000,-0.618,-0.976$, and -0.977 , respectively) and a significant positive correlation between $\mathrm{Pb}$ and $\mathrm{V}(\mathrm{r}=1.000)$. A significant positive correlation was found between $\mathrm{Zn}$ and all other elements $(\mathrm{r}=1.000)$.

Table 8 shows that $\mathrm{Al}$ correlated negatively with $\mathrm{Fe}(\mathrm{r}=-0.173)$ and Be correlated significantly positively with $\mathrm{Cd}(\mathrm{r}=1.000)$. Ba correlated negatively with $\mathrm{Fe}$ and $\mathrm{Ni}(\mathrm{r}=-0.135$ and -0.347 , respectively) and Ca correlated positively with $\mathrm{Cu}, \mathrm{Mg}$, $\mathrm{Mn}$, and $\mathrm{Mo}(\mathrm{r}=1.000,1.000,1.000$, and 0.999, respectively) and negatively with $\mathrm{Zn}(\mathrm{r}=-0.079)$. Co correlated positively with $\mathrm{Mo}(\mathrm{r}=0.998)$. A significant negative correlation existed between $\mathrm{Cr}$ and $\mathrm{Fe}(\mathrm{r}=-0.999)$. Cu correlated positively with $\mathrm{Mg}$, Mn, and Mo ( $\mathrm{r}=1.000,1.000$, and 0.999 , respectively) and negatively with $\mathrm{Fe}(\mathrm{r}=-0.838)$. Fe correlated negatively with $\mathrm{Mg}, \mathrm{Mn}, \mathrm{Mo}$, and $\mathrm{Ni}(\mathrm{r}=-0.849,-0.839,-0.818$, and -0.883 , respectively). Mg correlated positively with Mn and Mo ( $\mathrm{r}=1.000$ and 0.998 , respectively). A positive correlation existed between $\mathrm{Mn}$ and $\mathrm{Mo}(\mathrm{r}=0.999)$. Pb correlated negatively with $\mathrm{Al}, \mathrm{Be}, \mathrm{Ca}, \mathrm{Cd}, \mathrm{Co}, \mathrm{Cr}$, and $\mathrm{Cu}$ $(\mathrm{r}=-0.519,-0.249,-0.436,-0.247,-0.331,-0.826$, and -0.422 , respectively). $\mathrm{V}$ correlates negatively with $\mathrm{Al}, \mathrm{Be}, \mathrm{Ca}, \mathrm{Cd}, \mathrm{Co}$, and $\mathrm{Cu}(\mathrm{r}=-0.429,-0.148,-0.341,-0.146,-0.232$, and -0.327 , respectively). $\mathrm{Zn}$ showed a negative correlation with $\mathrm{Al}, \mathrm{Ca}, \mathrm{Cr}, \mathrm{Cu}, \mathrm{Mg}, \mathrm{Mn}, \mathrm{Mo}, \mathrm{Ni}, \mathrm{Pb}$, and $\mathrm{V}(\mathrm{r}=-0.173,-0.079$, $-0.564,-0.063,-0.872,-0.935,-0.918,-0.888,-0.858$, and -0.530 , respectively). Other relations among elements showed low or no significant correlations. 
Table 7. Correlation between the concentrations of heavy metals in A. ochraceus of Site I (Riyadh).

\begin{tabular}{|c|c|c|c|c|c|c|c|c|c|c|c|c|c|c|c|c|}
\hline \multirow{2}{*}{ Variables } & \multicolumn{16}{|c|}{ Concentrations of Different Heavy Metals in Site I } \\
\hline & Al & $\mathrm{Be}$ & Ва & $\mathrm{Ca}$ & $\mathrm{Cd}$ & Co & $\mathrm{Cr}$ & $\mathrm{Cu}$ & $\mathrm{Fe}$ & $\mathrm{Mg}$ & Mn & Mo & $\mathrm{Ni}$ & $\mathbf{P b}$ & $\mathrm{V}$ & $\mathrm{Zn}$ \\
\hline Al & 1 & & & & & & & & & & & & & & & \\
\hline Be & 0.848 & 1 & & & & & & & & & & & & & & \\
\hline Ba & 0.751 & 0.987 & 1 & & & & & & & & & & & & & \\
\hline $\mathrm{Ca}$ & 0.928 & 0.985 & 0.943 & 1 & & & & & & & & & & & & \\
\hline $\mathrm{Cd}$ & 0.868 & $0.999 *$ & 0.980 & 0.991 & 1 & & & & & & & & & & & \\
\hline Co & 0.654 & 0.955 & 0.991 & 0.889 & 0.944 & 1 & & & & & & & & & & \\
\hline $\mathrm{Cr}$ & 0.069 & -0.469 & -0.607 & -0.307 & -0.435 & -0.709 & 1 & & & & & & & & & \\
\hline $\mathrm{Cu}$ & $1.000 *$ & 0.832 & 0.730 & 0.916 & 0.853 & 0.631 & 0.100 & 1 & & & & & & & & \\
\hline $\mathrm{Fe}$ & 0.943 & 0.623 & 0.487 & 0.751 & 0.653 & 0.365 & 0.398 & 0.952 & 1 & & & & & & & \\
\hline $\mathrm{Mg}$ & 0.900 & 0.994 & 0.964 & 0.998 * & 0.998 * & 0.918 & -0.372 & 0.886 & 0.703 & 1 & & & & & & \\
\hline Mn & 0.847 & $1.000^{* *}$ & 0.987 & 0.984 & 0.999 * & 0.956 & -0.471 & 0.831 & 0.622 & 0.994 & 1 & & & & & \\
\hline Mo & 0.935 & 0.607 & 0.469 & 0.736 & 0.636 & 0.345 & 0.417 & 0.946 & $1.000 *$ & 0.688 & 0.605 & 1 & & & & \\
\hline $\mathbf{N i}$ & -0.856 & $-1.000 * *$ & -0.984 & -0.987 & $-1.000 *$ & -0.951 & 0.456 & -0.840 & -0.635 & -0.996 & $-1.000 *$ & -0.618 & 1 & & & \\
\hline $\mathrm{Pb}$ & 0.948 & 0.973 & 0.922 & 0.998 * & 0.981 & 0.861 & -0.251 & 0.938 & 0.788 & 0.992 & 0.972 & 0.775 & -0.976 & 1 & & \\
\hline V & 0.947 & 0.974 & 0.924 & $0.999 *$ & 0.982 & 0.863 & -0.256 & 0.936 & 0.785 & 0.993 & 0.973 & 0.772 & -0.977 & 1.000 ** & 1 & \\
\hline $\mathrm{Zn}$ & $1.000 * *$ & $1.000 * *$ & 1.000 ** & 1.000 ** & 1.000 ** & 1.000 ** & 1.000 ** & 1.000 ** & 1.000 ** & $1.000 * *$ & 1.000 ** & 1.000 ** & $1.000 * *$ & 1.000 ** & $1.000 * *$ & 1 \\
\hline
\end{tabular}

* Correlation is significant at the 0.05 leve. ${ }^{* *}$ Correlation is significant at the 0.01 level. 
Table 8. Correlation between the concentrations of heavy metals in A. ochraceus of Site II (Taif).

\begin{tabular}{|c|c|c|c|c|c|c|c|c|c|c|c|c|c|c|c|c|}
\hline \multirow{2}{*}{ Variables } & \multicolumn{16}{|c|}{ Concentrations of Different Heavy Metals in Site I } \\
\hline & Al & Be & Ba & $\mathrm{Ca}$ & $\mathrm{Cd}$ & Co & $\mathrm{Cr}$ & $\mathrm{Cu}$ & $\mathrm{Fe}$ & Mg & Mn & Mo & $\mathrm{Ni}$ & $\mathbf{P b}$ & $\mathbf{V}$ & $\mathrm{Zn}$ \\
\hline Al & 1 & & & & & & & & & & & & & & & \\
\hline Be & 0.957 & 1 & & & & & & & & & & & & & & \\
\hline Ва & 0.566 & 0.781 & 1 & & & & & & & & & & & & & \\
\hline $\mathrm{Ca}$ & 0.995 & 0.980 & 0.642 & 1 & & & & & & & & & & & & \\
\hline $\mathrm{Cd}$ & 0.956 & 1.000 ** & 0.782 & 0.980 & 1 & & & & & & & & & & & \\
\hline Co & 0.978 & 0.996 & 0.725 & 0.994 & 0.996 & 1 & & & & & & & & & & \\
\hline $\mathrm{Cr}$ & 0.911 & 0.752 & 0.176 & 0.867 & 0.750 & 0.805 & 1 & & & & & & & & & \\
\hline $\mathrm{Cu}$ & 0.994 & 0.983 & 0.654 & 1.000 ** & 0.983 & 0.995 & 0.860 & 1 & & & & & & & & \\
\hline $\mathrm{Fe}$ & -0.893 & -0.724 & -0.135 & -0.846 & -0.723 & -0.780 & $-0.999 *$ & -0.838 & 1 & & & & & & & \\
\hline $\mathrm{Mg}$ & 0.996 & 0.979 & 0.638 & $1.000 * *$ & 0.979 & 0.993 & 0.870 & $1.000 *$ & -0.849 & 1 & & & & & & \\
\hline Mn & 0.994 & 0.983 & 0.652 & $1.000 * *$ & 0.982 & 0.995 & 0.861 & 1.000 ** & -0.839 & $1.000 *$ & 1 & & & & & \\
\hline Mo & 0.989 & 0.989 & 0.680 & $0.999 *$ & 0.989 & $0.998 *$ & 0.841 & $0.999 *$ & -0.818 & $0.998 *$ & $0.999 *$ & 1 & & & & \\
\hline $\mathrm{Ni}$ & 0.577 & 0.315 & -0.347 & 0.497 & 0.313 & 0.395 & 0.863 & 0.483 & -0.883 & 0.501 & 0.485 & 0.452 & 1 & & & \\
\hline $\mathbf{P b}$ & -0.519 & -0.249 & 0.410 & -0.436 & -0.247 & -0.331 & -0.826 & -0.422 & 0.848 & -0.441 & -0.423 & -0.389 & -0.998 * & 1 & & \\
\hline V & -0.429 & -0.148 & 0.502 & -0.341 & -0.146 & -0.232 & -0.764 & -0.327 & 0.790 & -0.346 & -0.328 & -0.293 & -0.985 & 0.995 & 1 & \\
\hline $\mathrm{Zn}$ & -0.173 & 0.120 & 0.714 & -0.079 & 0.122 & 0.035 & -0.564 & -0.063 & 0.598 & -0.084 & -0.065 & -0.028 & -0.904 & 0.932 & 0.964 & 1 \\
\hline
\end{tabular}

${ }^{*}$ Correlation is significant at the 0.05 level. ${ }^{* *}$ Correlation is significant at the 0.01 level. 


\section{Discussion}

Termites are an interesting and economically important group of social insects, scientifically classified in the order Blattodea and are widely distributed in tropical and subtropical regions [35]. They have a highly evolved social organization and hierarchical structure [36]. They also live in colonies of various sizes containing several different castes which may include workers, soldiers, nymphs, and larvae [37]. In termites, the soldier and worker mandibles play crucial roles in defense and feeding functions [38]. Their morphology might vary from one genus or even from one species to another and is therefore commonly used for the systematic description of termite species.

According to the present results, A. ochraceus was naturally recorded in both localities under investigation; this is consistent with data reported by Ahmad [39] and Roonwal and Rathore [40], whom stated that species of the genus Anacanthotermes belonging to the family Hodotermitidae are characterized as the termites of Blattodea. Furthermore, since the beginning of the century, termites have proved to be of great interest in the study of phylogenetic relations between different taxa, as illustrated by the previous studies of Lynch [41], Jenkins et al. [42], and Szalansky et al. [43]. In the present study, the $12 \mathrm{~S}$ rRNA region of the recovered termite species was amplified using the species-specific primers 12S-F/12S-R, designed previously by Murthy et al. [26]. It is apparent that the present phylogenetic tree strongly supported the taxonomic groups of termites into four major lineages-the Mastotermitidae, the Stolotermitidae plus Hodotermitidae plus Archotermopsidae (SHA clade), the Kalotermitidae, and the Neoisoptera (=Rhinotermitidae plus Termitidae). These results agree with data obtained by Cameron et al. [44] and Legendre et al. [45]. The phylogenetic analysis of termite evolution described here identified the Mastotermitidae as the sister group of the remaining extant termites (=Euisoptera). This result agreed with the result of Nalepa and Lenz [46], who demonstrated that the sister-grouping of Mastotermitidae plus Euisoptera is one of the few well-supported clades that are consistent with the morphological, biological, and genomic data. The second lineage of the SHA clade was also reported by Legendre et al. [47]. All these families have been previously considered as a single family, Hodotermitidae [39]; however, the diverse life-histories found in the group have supported their division into multiple families. In the present study, Hodotermitidae was considered a monophyly in origin; this result is consistent with the studies of Thompson et al. [48] and Inward et al. [49], who found that Hodotermitidae was a monophyletic family nested within the paraphyletic groups of Termopsidae and Serritermitidae. The Archotermopsidae, however, was found to be a non-monophyletic group in all studies, where its monophyly was testable, including the one in which it was proposed [50], and it might, therefore, be taxonomically more conservative to revert to a single family, Hodotermitidae. Stolotermitidae and Archotermopsidae have quite contrasting biology [51]. They were long considered a single family, the Termopsidae; however, their disjoint distribution stolotermitids occur in the southern hemisphere and archotermopsids in the northern hemisphere combined with their frequent non-monophyly in the phylogenetic analyses led Engel et al. [50] to raise the former to family status, Stolotermitidae, and to propose the Archotermopsidae as a new name for the northern termopsids as the type genus for this family was extinct and not closely related to the extant genera. The third major lineage was identified as the drywood termites, Kalotermidae. In almost all previous phylogenetic hypotheses, the Kalotermitids were monophyletic (paraphyletic with respect to Neoisoptera in Donovan et al. [52]). In the present study, their position seemed to be well supported as a sister group to Neoisoptera, as reported by Kambhampati and Eggleton [3], Inward et al. [49], Legendre et al. [47], Ware et al. [53], Lo and Eggleton [54], and Cameron et al. [44], who supported their position as the second diverging lineage after Mastotermes within the termites, and this presents a new hypothesis for the placement of this family. In addition, Ahmad [39] mentioned about the Kalotermitidae that "the imago-worker mandibles are essentially the same as in Mastotermitidae" and clustered Kalotermitidae and Mastotermes based on those mandibles.

The Neoisoptera has been universally supported by the previous and present phylogenetic analyses. The Rhinotermitidae was paraphyletic on our tree, just as has been found by Kambhampati et al. [55], Donovan et al. [52], Thompson et al. [48], and Lo et al. [56], who reported the same data with 
support for only two major clades: the early branching Rhinotermitinae and the late branching [Coptotermitinae plus Heterotermitinae]. Another possible explanation for the non-monophyly of Rhinotermitidae was long hypothesized because of the high behavioral, developmental and morphological diversity of this group as stated by Grassé [57]. In the present study, the monophyly of the Termitidae is well established and supported by our topology; this finding agreed with the results of Inward et al. [49]. Another family, which might also warrant reclassification, is the enigmatic Brazilian Serritermitidae, which has been recovered consistently within the part of the (paraphyletic) Rhinotermitidae in our analysis, rather than a sister group to the Rhinotermitidae plus Termitidae as suggested by Inward et al. [49]. Our topology recognized the species-rich pan-tropical genera Heterotermes and Nasutitermes presently within Blattodea. Our analysis suggests that the first one was monophyletic, and more extensive taxon sampling will be required for the determination of the second one; this was consistent with the opinion of Inward et al. [49]. In addition, the genomic sequences of the rRNA gene for the present Anacanthotermes species demonstrated the monophyly of the family Hodotermitidae and supported the taxonomic position of the present termite species, which is embedded deeply in the genus Anacanthotermes with a close relationship with the previously described A. ochraceus as a more related sister taxon. This data coincided with previous studies [39,40,47-49].

Metal accumulation around the world has increased with the onset of urbanization and industrialization [58]. Our study demonstrated that the evaluation of heavy metal concentration in soil and termites leads to the bio-assessment of heavy metal pollution. Termites accumulated high concentrations of metals more than soil in both localities under investigation, except for Co (Site I), and Mo (Site II). The concentrations of these contaminants were found in the hazardous levels that exceeded the permissible limits for mineral soil recommended by the standards of the Egyptian High Committee of Water [59], Saudi Standards Metrology and Quality Organization [60], and United States Environmental Protection Agency [61]. These results were consistent with Gadd [62], Bååth et al. [63], Pennanen et al. [64,65], and Zafar et al. [66], who stated that the elevated heavy metal concentrations in soil are one of the stress factors exerting a selection pressure on soil microorganisms. Similar results were observed by Jop [67] in several indigenous organisms captured along a metal pollution gradient such as aquatic insects, which showed a gradual increase in metal concentrations in various metal-sensitive and metal-detoxified sub-cellular fractions with increasing environmental metal levels. In addition, Giguère et al. [68] stated that these organisms were able to protect themselves against metal toxicity by increasing the proportion of metals in non-toxic forms. The body metal concentrations in termites originated from Site II were higher than in those originated from Site I; this result was consistent with the findings of Maavara et al. [69] and Rabitsch [70], who reported that metal accumulation in termites was studied in relation to the differences between casts, interspecific variation tissue specific accumulation and time-related effects. Furthermore, Rabitsch [71] suggested that the high metal accumulation capacity of termites is accomplished through active metal excretion. In the present study, Ca was accumulated in significantly higher concentration than other elements, while the least accumulated ones were $\mathrm{Co}$ and $\mathrm{Mo}$. Other elements such as $\mathrm{Cu}, \mathrm{Fe}$, and $\mathrm{Zn}$, are considered important and essential nutrients for organisms. However, they could be very toxic at high concentration for cells and cause metabolic damage as stated by Hackman [72], Warrington [17], Gadd [62], Bagatto and Shorthouse [73], Lu et al. [74], Zan et al. [75], and Cheruiyot et al. [76]. In addition, Roth-Holzapfel [77], Barajas-Aceves et al. [78] and Zafar et al. [66], who reported that the accumulation factor for grasshopper was $\mathrm{Cd}>\mathrm{Hg}>\mathrm{Pb}$, indicating that different metals have different affinities leading to bioaccumulation in different organisms. Moreover, Bose and Bhattacharyya [79] and Toth et al. [80] reported that the high bioaccumulation values might be related to heavy metal-binding capacity of tissues, available metals, interactions between physicochemical parameters, and different species grown in these soils.

In the present study, the high ratios of CF, PLI, and DC were recorded in both studied sites, with Site II showing higher values than Site I because of the characteristic features of the studied area, the possible explanation of these elevations according to Grzesiak and Sieradzki [81] is that the 
emission of pollutants from the petroleum industries into the environment has been considerably affecting the flora and fauna, which accumulate large amounts of associated heavy metals. Correlation analyses assist to reveal the relationship of termites with the concentration of elements in soil. The current investigation recorded a significant direct relationship between the presence of termites on the concentrations of $\mathrm{Al}, \mathrm{Cu}, \mathrm{Zn}, \mathrm{Be}, \mathrm{Cd}, \mathrm{Mn}, \mathrm{Ca}, \mathrm{Mg}, \mathrm{Pb}, \mathrm{V}$, and $\mathrm{Mo}$, while, a significant indirect correlation existed for $\mathrm{Ba}, \mathrm{Cr}, \mathrm{Ni}, \mathrm{Co}$, and Fe. This result agreed with Rogival et al. [82] reported linear relationships between the total metal concentrations and the bioavailable fraction in the soil and levels in wood mice tissues. In addition, Flannagan et al. [83] cited that a possible explanation for this correlation is that the inhibition of AChE activity in the heads of stonefly nymphs was linearly correlated with the concentrations in nymphs poisoned by fenitrothion. Furthermore, Ibrahim et al. [84] and Iyaka and Kakulu [85] demonstrated similar results for stoneflies and chironomids exposed to several organophosphorus compounds.

\section{Conclusions}

Therefore, it could be concluded that the molecular studies provide more information for accurate taxonomic identification along the species level of the harvester termite A. ochraceus inhabiting Saudi Arabia. The dominance of the terrestrial insects in these ecosystems and the differential responsiveness of species to environmental stressors have led to their extensive use as ecological indicators worldwide. In addition, advanced future studies are recommended for elucidating the effect of heavy metals on the development of different harvester termites.

Author Contributions: Conceptualization, R.A. and R.A.-G.; methodology, N.A.O.; software, R.A.-G.; validation, R.A. and N.A.O.; formal analysis, R.A.-G.; investigation, R.A.; resources, N.A.O.; data curation, R.A. and R.A.-G.; writing—original draft preparation, R.A.; writing—review and editing, R.A.-G.; visualization, N.A.O.; supervision, R.A.; project administration, R.A.; funding acquisition, R.A.

Funding: This research received no external funding.

Acknowledgments: This research project supported by a grant from the Research Centre of the Female Scientific and Medical Colleges, Deanship of Scientific Research, King Saud University, Saudi Arabia. The authors thank the Deanship of Scientific Research and RSSU at King Saud University for their technical support.

Conflicts of Interest: The authors have declared that they have no conflict of interest regarding the content of this article.

\section{References}

1. Eggleton, P.; Bignell, D.E.; Sands, W.A.; Mawdsley, N.A.; Lawton, J.H.; Wood, T.G.; Bignell, N.C. The diversity, abundance, and biomass of termites under differing levels of disturbance in the Mbalmayo Forest Reserve, southern Cameroon. Philos. Trans. R. Soc. Lond. Ser. B 1996, 351, 51-68.

2. Krishna, K.; Grimaldi, D.A.; Krishna, V.; Engel, M.S. Treatise on the Isoptera of the world. Bull. Am. Mus. Nat. Hist. 2013, 377, 1-2704. [CrossRef]

3. Kambhampati, S.; Eggleton, P. Phylogenetics and Taxonomy. In Termites: Evolution, Sociality, Symbioses, Ecology; Abe, T., Higashi, M., Bignell, D.E., Eds.; Kluwer Academic: Dordrecht, The Netherlands, 2000; pp. 1-24.

4. Ohkuma, M.; Yuzawa, H.; Amornsak, W.; Sornnuwat, Y.; Takematsu, Y.; Yamada, A.; Vongkaluang, C.; Sarnthoy, O.; Kirtibutr, N.; Noparatnaraporn, N.; et al. Molecular phylogeny of Asian termites (Isoptera) of the families Termitidae and Rhinotermitidae based on mitochondrial COII sequences. Mol. Phylogenet. Evol. 2004, 31, 701-710. [CrossRef] [PubMed]

5. Abe, T.; Bignell, D.E.; Higashi, M. Termites: Evolution, Sociality, Symbioses, Ecology; Kluwer Academic Publishers: Dordrecht, The Netherlands, 2000; 488p.

6. Bitsch, C.; Noirot, C. Gut characters and phylogeny of the higher termites (Isoptera: Termitidae). A cladistic analysis. Ann. Soc. Entomol. Fr. 2002, 38, 201-210.

7. De Meyer, M. Phylogenetic relationships within the fruit fly genus Ceratitis MacLeay (Diptera: Tephritidae), derived from morphological and plant evidence. Insect Syst. Evol. 2005, 36, 459-480. [CrossRef] 
8. Kirton, L.G. The importance of accurate termite taxonomy in the broader perspective of termite management. In Proceedings of the Fifth International Conference on Urban Pests, Singapore, 10-13 July 2005; Chow-Yang, L., William, H.R., Eds.; Perniagaan Ph'ng@ P\&Y Design Network: Penang, Malaysia, 2005.

9. Ball, S.L.; Armstrong, K.F. DNA barcodes for insect pest identification: A test case with tussock moths (Lepidoptera: Lymantriidae). Can. J. Forensic Res. 2006, 36, 337-350. [CrossRef]

10. Virgilio, M.; Backeljau, T.; Nevado, B.; De Meyer, M. Comparative performances of DNA barcoding across insect orders. BMC Bioinform. 2010, 11, 206. [CrossRef]

11. Miura, T.; Maekwa, K.; Kitade, O.; Abe, T.; Matsumoto, T. Phylogenetic relationships among subfamilies in higher termites (Isoptera: Termitidae) based on mitochondrial COII gene sequences. Ann. Entomol. Soc. Am. 1998, 91, 515-523. [CrossRef]

12. Kambhampati, S.; Blavk, W.C.; Rai, K.S. Random amplified polymorphic DNA of mosquito species and populations (Diptera: Culicidae): Techniques, statistical analysis, and applications. J. Med. Entomol. 1992, 29, 939-945. [CrossRef]

13. Qadir, A.; Malik, R.N.; Husain, S.Z. Spatio-temporal variations in water quality of Nullah Aik-tributary of the river Chenab, Pakistan. Environ. Monit. Assess. 2008, 140, 43-59. [CrossRef]

14. Atafar, Z.; Mesdaghinia, A.; Nouri, J.; Homaee, M.; Yunesian, M.; Ahmadimoghaddam, M.; Mahvi, A.H. Effect of fertilizer application on soil heavy metal concentration. Environ. Monit. Assess. 2010, 160, 83-89. [CrossRef] [PubMed]

15. Lee, C.S.L.; Li, X.; Shi, W.; Cheung, S.C.N.; Thornton, I. Metal contamination in urban, suburban, and country park soils of Hong Kong: A study based on GIS and multivariate statistics. Sci. Total Environ. 2006, 356, 45-61. [CrossRef] [PubMed]

16. Eeva, T.; Rantala, L.M.; Rantala, M.J.; Hakkarainen, H.; Eeva, T. Heavy metal pollution disturbs immune response in wild and populations. Environ. Pollut. 2004, 145, 324-328.

17. Warrington, $\mathrm{S}$. Relationship between $\mathrm{SO}_{2}$ dose and growth of the pea aphid, Acyrthosiphon pisum, on peas. Environ. Pollut. 1987, 43, 155-162. [CrossRef]

18. Mitterbock, F.; Fuhrer, E. Effects of fluoride-polluted spruce leaves on nun moth caterpillars (Lymantria monacha). J. Appl. Entomol. 1988, 105, 19-27.

19. Fountain, M.T.; Hopkin, S.P. Continuous monitoring of Folsomia candida (Insecta: Collembola) in a metal exposure test. Ecotoxicol. Environ. Saf. 2001, 48, 275-286. [CrossRef] [PubMed]

20. Sildanchandra, W.; Crane, M. Influence of sexual dimorphism in Chironomus riparius Meigen on toxic effects of cadmium. Environ. Toxicol. Chem. 2000, 19, 2309-2313. [CrossRef]

21. Nascarella, M.A.; Stoffolano, J.G.; Stanek, E.J.; Kostecki, P.T.; Calabrese, E.J. Hormesis and stage specific toxicity induced by cadmium in an insect model, the queen blowfly, Phormia regina Meig. Environ. Pollut. 2003, 124, 257-262. [CrossRef]

22. Musa, M.B.; Ajayi, F.A.; Abdulhadi, B.J. Denudation effect of termitaria and characterization of associated termite species in Laffia, Nasarawa State, Nigeria. Eur. Sci. J. 2014, 10, 186-195.

23. Heckel, P.F.; Keener, T.C. Sex differences noted in mercury bioaccumulation in Magicicada cassini. Chemosphere 2007, 69, 78-81. [CrossRef]

24. Zheng, D.M.; Wang, Q.C.; Zhang, Z.S.; Zhang, N.; Zhang, X.W. Bioaccumulation of total and methyl mercury by arthropods. Bull. Environ. Contam. Toxicol. 2008, 81, 95-100. [CrossRef] [PubMed]

25. Badawi, A.; Faregalla, A.A.; Dabbour, A.; Mostafa, S.A.S. Studies on the Termite's Problem in Saudi Arabia; Science Research Division, King Abdel-Aziz University: Jeddah, Saudi Arabia, 1986; pp. 99-105.

26. Murthy, S.; Rajeshwari, R.K.; Ramya, S.L.; Venkatesan, T.; Jalali, S.K.; Verghese, A. Genetic diversity among Indian termites based on mitochondrial 12S rRNA gene. Eur. J. Zool. Res. 2015, 4, 1-6.

27. Altschul, S.F.; Madden, T.L.; Schaffer, T.A.; Zhang, J.; Zhang, Z.; Miller, W.; Lipman, D.J. Gapped BLAST and PSI-BLAST: A new generation of protein database search programs. Nucleic Acid Res. 1997, 25, 3389-3402.

28. Thompson, J.D.; Gibson, T.J.; Plewniak, F.; Jeanmougin, F.; Higgins, D.G. The CLUSTAL-X windows interface: Flexible strategies for multiple sequence alignment aided by quality analysis tools. Nucleic Acids Res. 1997, 25, 4876-4882. [CrossRef] [PubMed]

29. Felsenstein, J. Confidence limits on phylogenies: An approach using the bootstrap. Evolution 1985, 39, 783-791. [CrossRef] [PubMed]

30. Tamura, K.; Nei, M. Estimation of the number of nucleotide substitutions in the control region of mitochondrial DNA in humans and chimpanzees. Mol. Biol. Evol. 1993, 10, 512-526. [PubMed] 
31. Tamura, K.; Stecher, G.; Peterson, D.; Filipski, A.; Kumar, S. MEGA6 molecular evolutionary genetics analysis version 60. Mol. Biol. Evol. 2013, 30, 2725-2729. [CrossRef] [PubMed]

32. Håkanson, L. Ecological risk index for aquatic pollution control: Sediment logical approach. Water Res. 1980, 14, 975-1001. [CrossRef]

33. Usero, J.; González-Regalado, E.; Gracia, I. Trace metals in the bivalve mollusc Chamelea gallina from the Atlantic Coast of Southern Spain. Mar. Pollut. Bull. 1996, 32, 305-310. [CrossRef]

34. Sures, B.; Steiner, W.; Rydlo, M.; Taraschewski, H. Concentrations of 17 elements in the zebra mussel (Dreissena polymorpha), in different tissues of perch (Perca fluviatilis), and in perch intestinal parasites (Acanthocephalus lucii) from the subalpin lake Mondsee (Austria). Environ. Toxicol. Chem. 1999, 18, 2574-2579. [CrossRef]

35. Kalleshwaraswamy, C.M.; Murthy, M.S.; Viraktamath, C.A.; Krishna Kumar, N.K. Occurrence of Tuta absoluta (Lepidoptera: Gelechiidae) in the Malnad and Hyderabad-Karnataka regions of Karnataka, India. Fla. Entomol. 2015, 98, 970-971. [CrossRef]

36. Gentz, M.C.; Rubinoff, D.; Grace, J.K. Phylogenetic analysis of subrranean termites (Coptotermes spp., Isoptera, Rhinotermitidae) indicates the origins of Hawaiian and North American invasions: Potential implications for invasion biology. Proc. Hawaiian Entomol. Soc. 2008, 40, 1-9.

37. Faragalla, A.A.; Alqhtani, M.H.; Abu Zeid, I.; Ahmed, M.M. DNA fingerprinting of some major genera of subterranean termites (Isoptera) (Anacanthotermes, Psammotermes and Microtermes) from Western Saudi Arabia. Acad. J. Entomol. 2015, 8, 104-109.

38. Deligne, J. Functional morphology and evolution of a Carpenter's plane-like tool in the mandibles of termite workers (Insecta, Isoptera). Belg. J. Zool. 1999, 129, 201-218.

39. Ahmad, M. The phylogeny of termite genera based on imagoworker mandibles. Bull. Am. Mus. Nat. Hist. 1950, 95, 37-86.

40. Roonwal, M.L.; Rathore, N.S. Evolution and systematic significance of wing micro-sculpturing in termites (Isoptera): New types in the Kalotermitidae and Hodotermitidae. Zool. Anz. 1978, 3, 219-232.

41. Lynch, R.E. Resistance in peanut to major arthropod pests. Fla. Entomol. 1990, 73, 422-455. [CrossRef]

42. Jenkins, B.N.; Dean, B.E.; Forschler, B.T. DNA technology, interstate commerce and the likely origin of the Formosan subterranean termites (Isoptera: Rhinotermitidae) infestation in Atlanta, Gerogia. J. Econ. Entomol. 2002, 95, 381-389. [CrossRef]

43. Szalansky, A.L.; Austin, J.W.; Owens, C.B. Identification of Reticulotermes spp. (Isoptera: Reticulotermitidae) from the South Central United States by PCR-RFLP. J. Econ. Entomol. 2003, 96, 1514-1519. [CrossRef]

44. Cameron, S.L.; Lo, N.; Bourguignon, T.; Svenson, G.J.; Evans, T.A. A mitochondrial genome phylogeny of termites (Blattodea: Termitoidae): Robust support for interfamilial relationship and molecular synapomorphies define major clades. Mol. Phylogenet. Evol. 2012, 65, 163-173. [CrossRef]

45. Legendre, F.; Nel, A.; Svenson, G.J.; Robillard, T.; Pellens, R.; Grandcolas, P. Phylogeny of Dictyoptera: Dating the origin of cockroaches, praying mantises and termites with molecular data and controlled fossil evidence. PLoS ONE 2015, 10, e130127. [CrossRef]

46. Nalepa, C.A.; Lenz, M. The ootheca of Mastotermes darwiniensis Froggatt (Isoptera: Mastotermitidae): Homology with cockroach oothecae. Proc. R. Soc. Lond. Ser. B 2000, 267, 1809-1813. [CrossRef] [PubMed]

47. Legendre, F.; Whiting, M.F.; Bordereau, C.; Cancello, E.M.; Evans, T.A.; Grandcolas, P. The phylogeny of termites (Dictyoptera: Isoptera) based on mitochondrial and nuclear markers: Implications for the evolution of the worker and pseudergate castes, and foraging behaviors. Mol. Phylogenet. Evol. 2008, 48, 615-627. [CrossRef] [PubMed]

48. Thompson, G.J.; Kitade, O.; Lo, N.; Crozier, R.H. Phylogenetic evidence for a single ancestral origin of a 'true' worker caste in termites. J. Evol. Biol. 2000, 13, 869-881. [CrossRef]

49. Inward, D.J.G.; Vogler, A.P.; Eggleton, P. A comprehensive phylogenetic analysis of termites (Isoptera) illuminates key aspects of their evolutionary biology. Mol. Phylogenet. Evol. 2007, 44, 953-967. [CrossRef] [PubMed]

50. Engel, M.S.; Grimaldi, D.A.; Krishna, K. Termites (Isoptera): Their phylogeny, classification and rise to ecological dominance. Am. Mus. Novit. 2009, 3650, 1-27. [CrossRef]

51. Lacey, M.J.; Lenz, M.; Evans, T.A. Cryoprotection in dampwood termites (Termopsidae: Isoptera). J. Insect Physiol. 2010, 56, 1-7. [CrossRef]

52. Donovan, S.E.; Jones, D.T.; Sands, W.A.; Eggleton, P. Morphological phylogenetics of termites (Isoptera). Biol. J. Linn. Soc. 2000, 70, 467-513. [CrossRef] 
53. Ware, J.L.; Grimaldi, D.A.; Engel, M.S. The effects of fossil placement and calibration on divergence times and rates: An example from the termites (Insecta: Isoptera). Arthropod Struct. Dev. 2010, 39, 204-219. [CrossRef]

54. Lo, N.; Eggleton, P. Termite phylogenetics and co-cladogenesis with symbionts. In Biology of Termites: A Modern Synthesis; Bignell, D.E., Roisin, Y., Lo, N., Eds.; Springer: Dordrecht, The Netherlands, 2011; pp. 27-50.

55. Kambhampati, S.; Kjer, K.M.; Thorne, B.L. Phylogenetic relationship among termite families based on DNA sequence of mito 16S ribosomal RNA gene. Insect Mol. Biol. 1996, 5, 229-238. [CrossRef]

56. Lo, N.; Kitade, O.; Miurua, T.; Constantino, R.; Matsumoto, T. Molecular phylogeny of the Rhinotermitidae. Insectes Sociaux 2004, 51, 365-371. [CrossRef]

57. Grassé, P.P. Termitologia: Comportement, Socialité, Ecologie, Evolution, Systématique; Masson: Paris, France, 1986; 716p.

58. Hladun, K.R.; Parker, D.R.; Trumble, J.T. Cadmium, copper, and lead accumulation and bioconcentration in the vegetative and reproductive organs of Raphanus sativus: Implications for plant performance and pollution. J. Chem. Ecol. 2015, 41, 386-395. [CrossRef] [PubMed]

59. Egyptian Higher Committee of Water (EHCW). Egyptian Standards for Drinking and Domestic Water According to the Act 27/1978 in Regulating of the Public Water Supplies; Egyptian Governmental Press: Cairo, Egypt, 1995.

60. SASO (Saudi Arabian Standards Organization). Maximum Limits of Contaminating Metallic Elements in Foods; Saudi Standards, Metrology and Quality Organization: Riyadh, Saudi Arabia, 1997.

61. United States Environmental Protection Agency (USEPA). Trace Elements in Water, Solids, and Biosolids by Inductively Coupled Plasma-Atomic Emission Spectrometry; EPA Method: Washington, DC, USA, 1998.

62. Gadd, G.M. Interaction of fungi with toxic metals. New Phytol. 1993, 124, 25-60. [CrossRef]

63. Bååth, E.; Diaz-Ravina, M.; Frostegard, A.; Campbell, C.D. Effect of metal-rich sludge amended on the soil microbial community. Appl. Environ. Microbiol. 1998, 64, 238-245. [PubMed]

64. Pennanen, T.; Fostegråd, Å.; Fritze, H.; Bååth, E. Phospholipid fatty acid composition and heavy metal-polluted gradients in coniferous forests. Appl. Environ. Microbiol. 1996, 62, 420-428. [PubMed]

65. Pennanen, T.; Perkiömäki, J.; Kiikkilä, O.; Vanhala, P.; Neuvonen, S.; Fritze, H. Prolonged, simulated acid rain and heavy metal deposition: separated and combined effects on forest soil microbial community structure. FEMS Microbiol. Ecol. 1998, 27, 291-300. [CrossRef]

66. Zafar, S.; Aqil, F.; Ahmad, I. Metal tolerance and biosorption potential of filamentous fungi isolated from metal contaminated agricultural soil. Bioresour. Technol. 2007, 98, 2557-2561. [CrossRef] [PubMed]

67. Jop, K.M. Concentration of metals in various larval stages of four Ephemeroptera species. Bull. Environ. Contam. Toxicol. 1991, 46, 901-905. [CrossRef]

68. Giguère, A.; Campbell, P.G.C.; Hare, L.; Couture, P. Sub-cellular partitioning of cadmium, copper, nickel and zinc in indigenous yellow perch (Perca flavescens) sampled along a pollymetallic gradient. Aquat. Toxicol. 2006, 77, 178-189. [CrossRef]

69. Maavara, V.; Martin, A.J.; Oja, A.; Nuorteva, P. Sampling of different social categories of red wood ants (Formica s. str.) for biomonitoring. In Environmental Sampling for Trace Metal; Market, B., Ed.; VCH: Weinheim, Germany, 1994; pp. 466-489.

70. Rabitsch, W.B. Metal accumulation in arthropods near e lead/zinc smelter in Arnoldstein, Austria. II. Formicidae. Environ. Pollut. 1995, 90, 239-247. [CrossRef]

71. Rabitsch, W.B. Tissue-specific accumulation patterns of $\mathrm{Pb}, \mathrm{Cd}, \mathrm{Cu}, \mathrm{Zn}, \mathrm{Fe}$, and $\mathrm{Mn}$ in workers of three ant species (Formicidae: Hymenoptera) from a metal-polluted site. Arch. Environ. Contam. Toxicol. 1997, 32, 172-177. [CrossRef]

72. Hackman, R. Chemistry of the insect cuticle. In The Physiology of Insecta, 2nd ed.; Rockstein, M., Ed.; Academic Press, Inc.: London, UK, 1974; pp. 215-270.

73. Bagatto, G.; Shorthouse, J.D. Accumulation of $\mathrm{Cu}$ and $\mathrm{Ni}$ in successive stages of Lymantria dispar L. (Lymantriidae: Lepidoptera) near ore smelters at Sudbury, Ontario, Canada. Environ. Pollut. 1996, 92, 7-12. [CrossRef]

74. Lu, G.; Di, S.; Xueping, Z. Analysis on the current pollution situation of $\mathrm{Cu}, \mathrm{Pb}$ and $\mathrm{Zn}$ in the cultivated black soil of songnen plain. Chin. Agric. Sci. Bull. 2011, 27, 261-265.

75. Zan, S.T.; Yang, R.Y.; Wang, W.W. The correlation of soil physicochemical properties and copper-zinc accumulation of Elsholtzia splendens. J. Biol. 2011, 28, 46-49. 
76. Cheruiyot, D.J.; Boyd, R.S.; Coudron, T.A.; Cobine, P.A. Bioaccumulation and effects of herbivore dietary Co, $\mathrm{Cu}, \mathrm{Ni}$, and $\mathrm{Zn}$ on growth and development of the insect predator Podisus maculiventris (Say). J. Chem. Ecol. 2013, 39, 764-772. [CrossRef] [PubMed]

77. Roth-Holzapfel, M. Multi-element analysis of invertebrate animals in a forest ecosystem (Picea abies L.). In Element Concentration Cadasters in Ecosystems; Lieth, H., Markert, B., Eds.; VCH Verlagsgesellschaft: Weinheim, Germany, 1990; pp. 281-295.

78. Barajas-Aceves, M.; Grace, C.; Ansorena, J.; Dendooven, L.; Brookes, P.C. Soil microbial biomass and organic $\mathrm{C}$ in a gradient of zinc concentrations in soils around a mine spoil tip. Soil Biol. Biochem. 1999, 31, 867-876. [CrossRef]

79. Bose, S.; Bhattacharyya, A.K. Heavy metal accumulation in wheat plant grown in soil amended with industrial sludge. Chemosphere 2008, 70, 1264-1272. [CrossRef] [PubMed]

80. Toth, T.; Tomas, J.; Lazor, P.; Bajcan, D.; Jomova, D. The transfer of metals from contaminated soils into agricultural plants in high Tatars region, Czech. J. Food Sci. 2009, 27, 390-393.

81. Grzesiak, M.; Sieradzki, Z. Environment. Information and Statistical Papers; Statistical Publications House: Warsaw, Poland, 2000.

82. Rogival, D.; Scheirs, J.; Blust, R. Transfer and accumulation of metals in a soil-diet-wood mouse food chain along a metal pollution gradient. Environ. Pollut. 2007, 145, 516-528. [CrossRef]

83. Flannagan, J.F.; Lockhart, W.L.; Cobb, D.G.; Metner, D. Stonefly (Plecoptera) head cholinesterase as an indicator of exposure to fenitrothion. Manit. Entomol. 1978, 12, 42-48.

84. Ibrahim, H.; Kheir, R.; Helmi, S.; Lewis, J.; Crane, M. Effects of organophosphorus, carbamate, pyrethroid and organochlorine pesticides, and a heavy metal on survival and cholinesterase activity of Chironomus riparius Meigen. Bull. Environ. Contam. Toxicol. 1998, 60, 448-455. [CrossRef]

85. Iyaka, Y.A.; Kakulu, S.E. Copper and zinc contents in urban agricultural soils of Niger State, Nigeria. Int. Multi-Discip. J. Ethiop. 2009, 3, 23. [CrossRef]

(C) 2019 by the authors. Licensee MDPI, Basel, Switzerland. This article is an open access article distributed under the terms and conditions of the Creative Commons Attribution (CC BY) license (http:// creativecommons.org/licenses/by/4.0/). 